\title{
Something Free or Something Off? A Comparative Study of the Purchase Effects of Premiums and Price Cuts
}

\author{
Bram Foubert* \\ Maastricht University, Department of Marketing and Supply Chain Management, \\ Tongersestraat 53, 6200 MD Maastricht, Netherlands, phone: +31 43388 3816, \\ fax: +31 43388 4918, e-mail: b.foubert@maastrichtuniversity.nl
}

\section{Els Breugelmans}

KU Leuven, Faculty of Economics and Business, Department of Marketing Management, Korte Nieuwstraat 33, 2000 Antwerp, Belgium, phone: + 323201 1891, fax: +32 3201 1899, e-mail: els.breugelmans@kuleuven.be

\section{Karen Gedenk}

University of Hamburg, Department of Marketing and Media Research, Welckerstraße 8, 20354 Hamburg, Germany, phone: +49 4042838 8609, fax: +49 4042838 8607, e-mail: karen.gedenk@wiso.uni-hamburg.de

\section{Charlotte Rolef}

IAL-Campus, Lepperhammer 2, 51766 Engelskirchen, Germany, phone: +49 226390 2354-30, fax: +49 226390 2354-99,

e-mail: charlotte.rolef@ial-campus.de

Published as: B. Foubert, E. Breugelmans, K. Gedenk and C. Rolef, (2017) "Something Free or Something Off? A Comparative Study of the Purchase Effects of Premiums and Price Cuts", Forthcoming Journal of Retailing.

* Corresponding author 


\title{
Something Free or Something Off? A Comparative Study of the Purchase Effects of Premiums and Price Cuts
}

\begin{abstract}
As an alternative to promotional price cuts, retailers and manufacturers often rely on nonprice promotion techniques, such as premium promotions, where consumers receive a free gift with the purchase of a product. We compare the effectiveness of premiums to that of price cuts, and study moderators of this comparative premium effectiveness. We use data from a large online shopping simulation study with more than 2,000 participants to model consumers' purchase decisions in response to premiums and price cuts. Results indicate that the impact of premiums on purchase behavior is systematically lower than that of equivalent price cuts. However, a premium's smaller sales impact may be offset by a cost advantage. This is especially true for private label brands where the premium's purchase effects do not differ too much from those of a price cut. We calculate how large the cost advantage has to be for a premium to be more profitable than a price cut, and show that premiums entail risks as well as opportunities, for both manufacturers and retailers.
\end{abstract}

Keywords: Sales Promotion, Premiums, Price Cuts, Retailing, Purchase Decisions 


\section{Introduction}

Although price-based incentives remain the most common type of sales promotion, nonmonetary techniques have become increasingly popular (Buil, de Chernatony and Montaner 2013). The use of premium promotions is one such technique, where consumers receive a free gift (the premium) with the purchase of a product (d'Astous and Jacob 2002). For example, McDonald's Happy Meal comes with a free toy, and beer is often promoted with a free glass. In the US, the industry for promotional products used as free gifts for customers, had revenues of \$21 billion in 2016 (IBISWorld 2016).

Like promotional price cuts, premium promotions are often initiated by manufacturers (Ailawadi and Harlam 2009; Walters 1989; Kumar, Rajiv and Jeuland 2001). In a survey of marketing managers of FMCG manufacturers in Germany (Rudek 2008), 82\% of the respondents indicated that they use premiums in their strategic business units. Still, similar to price cuts (Ailawadi and Harlam 2009), premiums can also be the sole initiative of the retailer. The retailer is the final gatekeeper in deciding which promotions to offer in his stores, but a manufacturer can provide premiums or trade promotions to the retailer and encourage pass-through.

Both manufacturers and retailers need to trade off different promotion forms. Therefore, it is a crucial question how a premium's effectiveness compares to that of an (equivalent) price cut under various conditions. Yet, research to date does not offer clear answers. Like promotional price cuts (e.g., Ailawadi and Gupta 2014), premiums have received substantial attention in the marketing literature (e.g., Low and Lichtenstein 1993; d'Astous and Jacob 2002; Shimp, Dyer and Divita 1976). Nonetheless, there is a striking paucity of research comparing the impact of both promotion forms. A few studies tap into "comparative premium effectiveness," which we define as the purchase effects of a premium relative to those of an equivalent price cut (e.g., Darke and Chung 2005; Chandran and 
Morwitz 2006). However, these studies mostly focus on subjective evaluations (e.g., the promoted brand's perceived quality) and not on consumers' purchase decisions. Moreover, little is known about the moderators of comparative premium effectiveness.

The objective of this paper is to compare the immediate effects of premiums and equivalent price cuts on consumers' purchase decisions. In addition, we examine two potential moderators, the importance of which has been shown for the effects of either premiums or price cuts, but not for comparative premium effectiveness. These moderators are characteristics of the premium promotion (i.e., its functional relatedness to the category) and the promoted brand (i.e., national brand versus private label). In line with many previous studies and examples in practice, we focus on premiums that are meant to increase the sales of the product to which they are tied (i.e., they are not samples for other products) and that are not part of a collection (e.g., Palazon and Delgado-Ballester 2013; Nunes and Park 2003; Chandran and Morwitz 2006).

We set up an online simulated shopping environment, in which more than 2,000 participants made fictitious purchase decisions in four fast-moving consumer good (FMCG) categories: orange juice, cereals, margarine, and milk. A shopping simulation experiment offers complete control over the purchase environment and at the same time provides realistic buying behavior data (Campo, Gijsbrechts and Guerra 1999). We use our data to model the effects of premiums and price cuts on consumers' brand choice decisions (which in a nested logit model carry through to purchase incidence decisions) and purchase quantity decisions.

We find that premiums systematically generate smaller purchase effects than equivalent price cuts, at the choice as well as at the quantity level. However, a premium's smaller sales impact may be offset by a cost advantage. We calculate how large this cost advantage has to be for premiums to be more profitable than price cuts. Our results suggest that premiums may be a cost-effective alternative to price cuts, especially when the focus is 
on SKU sales, rather than on overall category sales, and when the promoted brand is a private label. Interestingly, a premium's functional relatedness to the category usually does not influence comparative premium effectiveness.

In what follows, we first discuss our contribution to the literature and develop hypotheses. Next, we describe the experiment, present our model, and discuss the results. We then use our estimates to compute the impact of price and premium promotions on brand and category sales, and to derive premium indifference costs. A discussion of implications for management and research concludes the paper.

\section{Previous Literature and Contribution}

A vast body of research has studied the purchase and sales effects of promotional price cuts and the features and displays that support them. Since this literature has already been summarized, for example by Ailawadi and Gupta (2014) and Neslin (2006), we refrain from reviewing it again. In general, researchers find large sales boosts from price cuts. Yet, price cuts come at a huge cost because they decrease profit margins. Analyzing 93 million trade promotions in different countries around the world, Nielsen finds that $59 \%$ of trade promotions were unprofitable for FMCG manufacturers in 2015 (Nielsen 2016). For grocery retailers, this number ranges from 50\% (Ailawadi et al. 2006) to 94\% (Srinivasan et al. 2004). Interestingly, Ailawadi et al. (2006) show that drivers which increase a promotion's sales impact, typically decrease its profitability for a retailer.

Given the concerns about the cost-effectiveness of price cuts, research has explored the potential of non-monetary promotions such as sampling (e.g., Bawa and Shoemaker 2004; Gedenk and Neslin 1999) and cause marketing (e.g., Arora and Henderson 2007). Similarly, researchers have examined the effects of premium promotions. They show that premiums can improve consumers' attitude towards and preference for the promoted brand (Shimp, Dyer 
and Divita 1976; Low and Lichtenstein 1993; Chang 2009), generate favorable brand associations (Palazón-Vidal and Delgado-Ballester 2005), and increase the perceived value of an offer (Darke and Chung 2005). At the same time, previous work has found that premiums with little or no value can reduce the purchase likelihood for the promoted brand, for example, because consumers perceive them as a blunt marketing gimmick designed to boost sales (e.g., Simonson, Carmon and O'Curry 1994; Gedenk, Hartmann and Schulze 2000; Gedenk, Hoffmann and Fantapié Altobelli 2013).

Our work contributes to the premium promotion literature in two ways. First, we explicitly compare the purchase effects of premium promotions with those of price cuts. Surprisingly little research has measured this comparative premium effectiveness. The few studies that do address the issue (see top part of Table 1) have produced mixed results, with premiums having stronger, weaker, or similar effects than price cuts (e.g., Chou and Lien 2012; Chandran and Morwitz 2006; Darke and Chung 2005). Moreover, these studies almost exclusively consider the effects on consumers' subjective evaluations (e.g., attitudes), collected through highly-stylized scenario-based survey experiments, and ignore purchase behavior. However, purchase behavior involves mechanisms that may go unaccounted for in subjective measures. For instance, more so than a price cut, a premium may cause reactance effects whereby consumers refuse to choose the promoted product because they feel manipulated by the marketer. Also, consumers may be less inclined to buy large quantities of a premium-promoted product because the marginal value of a typical gift decreases with each additional unit. Interestingly, Nunes and Park (2003), who provide the only study based on objective performance data, find the effectiveness of premiums to be worse than or at best similar to that of price cuts. Still, Nunes and Park study aggregate brand sales, and thus cannot, for example, distinguish between choice and quantity decisions. 
Second, we study how the effectiveness of premiums compared to that of price cuts is influenced by two moderators. Previous research has tried to explain the variance in comparative premium effectiveness by variables like price or package size of the promoted product (e.g., Nunes and Park 2003; Palazon and Delgado-Ballester 2009). We focus on moderators that have been shown to be important for the effectiveness of either premiums or price cuts, but have not been studied in the context of comparative premium effectiveness. These moderators are the functional relatedness of the premium to the category, and whether the promoted product is a national brand or private label. In the bottom part of Table 1, we summarize extant work on the effects of these moderators on absolute premium effectiveness. With respect to national brands versus private labels, research has addressed the role of brand equity in the form of brand attitude (Buil, de Chernatony and Montaner 2013; d'Astous and Jacob 2002) and quality (Montaner, de Chernatony and Buil 2011; Gaeth et al. 1990). Furthermore, prior literature has examined the impact of a premium's functional relatedness on, for example, attitude toward the promoted product and purchase intention (e.g., Harlam et al. 1995; Jones 2008; Jones 2015). However, none of these papers compare the effects of a premium with those of a price cut.

Pursuing these two objectives poses a methodological challenge. Field data is best for measuring purchase behavior, but systematically manipulating several variables of interest (in our case matching premiums to equivalent price cuts, and varying the two moderators) while controlling for other factors, would be extremely difficult. In contrast, scenario-based survey experiments safeguard internal validity but score low on external validity. We therefore choose a research method that combines the best of both worlds: an online purchase simulation in which respondents are shown supermarket shelves in different product categories and are asked to make grocery purchases. Such a purchase simulation provides 
realistic buying behavior data (Campo, Gijsbrechts and Guerra 1999; Burke et al. 1992), and at the same time allows for extensive control.

When setting up our purchase simulation, we pay particular attention to the equivalence of premiums and price cuts. In previous research, Chandran and Morwitz (2006), Darke and Chung (2005), and Nunes and Park (2003) compare price cuts and premiums with equivalent retail value. Yet, a premium's retail value may not equal the value perceived by consumers, such that differences in effectiveness between premiums and price cuts may be merely due to differences in the promotions' perceived value. In turn, Chou and Lien (2012), Palazon and Delgado-Ballester (2009), and Palazon and Delgado (2009) determine the equivalent price cut as the price cut that makes the consumer indifferent between the two promotion types. However, this price cut may be substantially lower than the premium's intrinsic value: once a premium is offered for free as a promotional incentive, it may trigger devaluation or reactance effects (Darke and Chung 2005). As a result, the premium would be compared with an unduly low price cut, leading to an overstatement of the premium's comparative performance. To address these concerns, we establish the equivalence of premiums and price cuts on the basis of consumers' willingness-to-pay for the premium if it were offered for sale separately. In our main analysis, we then measure the extent to which such equivalent premiums and price cuts lead to different purchase effects in a promotion context.

\section{Hypotheses}

Figure 1 depicts our conceptual framework. We develop hypotheses about (1) the purchase effects of premiums compared to those of equivalent price cuts, and (2) the impact of two moderators on this comparative premium effectiveness. We study the effects on a consumer's decisions whether to buy the category (purchase incidence), which brand to buy (brand 
choice), and how many units to buy (purchase quantity) (e.g., Bell, Chiang and Padmanabhan 1999; Ailawadi et al. 2007). We formulate hypotheses for the choice and quantity effects. As we explain in more detail in the model section, we estimate a nested logit model where the effects in the brand choice model carry through to the incidence model. More specifically, the attractiveness of buying in a category depends on the attractiveness of the individual brands making up the category (Bucklin and Gupta 1992; Ailawadi et al. 2007; Bezawada and Pauwels 2013). Thus, the effects of premiums and price cuts on purchase incidence follow the effects on brand choice.

-- Insert Figure 1 about here --

\subsection{Comparative Premium Effectiveness}

We compare a premium to a price cut that equals the premium's perceived value in isolation. Once the premium is used as a free gift in a promotional context, the premium's impact on purchase behavior may differ from that of the equivalent price cut. We derive our expectation about the direction of this difference from several theories and previous empirical findings. On the one hand, prospect theory (Kahneman and Tversky 1979) suggests that premiums may be more attractive than equivalent monetary promotions because consumers encode the former as separate gains and not merely as reductions of the price to be paid (e.g., Darke and Chung 2005; Chandran and Morwitz 2006).

On the other hand, there are several reasons why a premium may be less effective than an equivalent price cut. First, the money saved from a price cut is completely fungible and can be allocated flexibly, while a premium's benefits are fixed (e.g., Heilman, Nakamoto and Rao 2002). Second, the fact that the premium is offered for free may trigger a devaluation effect such that the premium is perceived as of lower quality and less valuable (Raghubir 2004; Raghubir 2005). Third, a premium promotion - more so than a price cut - may be 
perceived as a blunt marketing gimmick designed to boost sales (Gedenk, Hartmann and Schulze 2000; Simonson, Carmon and O'Curry 1994). In line with the object-perception principle of attribution theory, consumers may attribute such obvious marketing effort to the manufacturer's or retailer's fear of dismal sales and infer that the brand is of low quality (e.g., Darke and Chung 2005; Raghubir and Celly 2011). Similarly, reactance theory (Brehm 1966) implies that consumers may feel manipulated and therefore refuse to act in accordance with the suggested behavior (Simonson, Carmon and O'Curry 1994).

At the quantity level, there is an additional mechanism that reduces comparative premium effectiveness. Consumers who increase their purchase quantity in response to a premium promotion obtain multiple units of the same premium. Whereas the marginal (monetary) value of a price cut is constant, economic theory suggests that a premium's marginal value diminishes with each additional unit (at least for premiums that are not part of a collection, like the ones we study) (e.g., Horowitz, List and McConnell 2007).

Given the prevalence of arguments in favor of price cuts, we expect a premium to have a smaller impact on consumers' purchase decisions. Therefore, we pose:

$\mathrm{H}_{1 \mathrm{a}}$ : On average, a premium increases consumers' brand choice probability less than an equivalent price cut.

$\mathrm{H}_{1 \mathrm{~b}}$ : On average, a premium increases consumers' purchase quantity less than an equivalent price cut.

\subsection{Moderators of Comparative Premium Effectiveness}

Our main hypothesis suggests that price cuts are superior to premiums. In what follows, we evaluate how the functional relatedness of the premium and the nature of the brand may mitigate the premium's inferiority, i.e., its comparative effectiveness. 
Functionally Related versus Unrelated Premiums. Functional relatedness is high when the premium and the promoted product are considered complements that are likely to be used together (Aaker and Keller 1990). Previous premium research has shown that functional relatedness increases the attitudes towards premiums (e.g., Harlam et al. 1995; Jones 2008; Jones 2015). Also the bundling literature indicates that consumers have a greater willingnessto-pay for and more positive attitude towards items that are functionally compatible (Venkatesh and Kamakura 2003; Simonin and Ruth 1998). Similarly, relatedness of the premium with the product category may increase the value consumers attach to the combined offer, a principle that may strengthen comparative premium effectiveness at both the choice and the quantity level. Functional relatedness may also temper perceptions of manipulation, thereby lowering possible negative reactance effects (Kivetz 2005). In sum, we expect that functional relatedness improves the attractiveness of the premium, thereby reducing the superiority of the price cut. Hence, we expect that:

$\mathrm{H}_{2 \mathrm{a}}$ : At the brand choice level, the comparative effectiveness of a functionally related premium is higher than that of an unrelated premium.

$\mathrm{H}_{2 b}$ : At the purchase quantity level, the comparative effectiveness of a functionally related premium is higher than that of an unrelated premium.

Private Label versus National Brand. Previous research has shown that both premiums (d'Astous and Jacob 2002; Buil, de Chernatony and Montaner 2013; Montaner, de Chernatony and Buil 2011) and price cuts (e.g., Blattberg and Wisniewski 1989; Sivakumar and Raj 1997) tend to be more effective for national brands than for private labels. This may be the case for two reasons. First, consumers tend to be more attentive to marketing actions of well-known brands (e.g., d'Astous and Jacob 2002; Buil, de Chernatony and Montaner 2013). This applies to premiums as well as price cuts, and therefore does not affect comparative premium effectiveness. In contrast, the second reason holds only for price cuts, and not for 
premiums: a lower price makes national brands affordable to price-sensitive consumers, who usually purchase the cheaper private labels but now have the opportunity to buy and stock up on an otherwise too expensive product. A price cut for a private label will have a smaller effect because buyers of national brands may not want to give up quality to benefit from the private label's lower price (e.g., Blattberg and Wisniewski 1989; Sivakumar and Raj 1997). Hence, we expect that the superiority of price cuts over premiums is smaller for private labels than for national brands:

$\mathrm{H}_{3 \mathrm{a}}$ : At the brand choice level, the comparative effectiveness of a premium is higher for private labels than for national brands.

$\mathrm{H}_{3 b}$ : At the purchase quantity level, the comparative effectiveness of a premium is higher for private labels than for national brands.

\section{Data}

To collect data for this study, we used an online purchase simulation in which we mimicked a realistic grocery shopping environment. Respondents, all members of a research panel in a West European country, made fictitious purchases in different product categories with varying promotions over a fictitious period of seven weeks. Computer-simulated shopping experiments can provide realistic buying behavior data, especially when cues such as brands, prices, and promotions resemble those of a real shopping environment (Burke et al. 1992; Campo, Gijsbrechts and Guerra 1999). Such experiments are particularly useful when the shopping context needs to be carefully manipulated and the costs of a field experiment would be prohibitively large (e.g., Massara, Melara and Liu 2014; Breugelmans, Campo and Gijsbrechts 2006). In our research, we matched the premium value with an equivalent price cut, and manipulated the two moderators. 
To check whether our findings generalize, we studied purchase behavior in four different product categories: margarine, milk, orange juice, and cereals. In the Appendix, we explain how we selected the categories and their assortments, and how we determined regular price levels and the SKUs to be promoted. Below, we explain how we chose the premiums and price cut levels, and discuss survey design and sample characteristics. In Table 2, we report assortment and promotion characteristics for each of the four categories.

-- Insert Table 2 about here --

\subsection{Selection of Premiums}

To select functionally related and unrelated premiums with the same perceived value, we proceeded as follows. In a first pre-test, we showed respondents pictures and brief descriptions of a random selection of 13 out of 39 possible (related and unrelated) premiums and asked how much they would maximally pay for each item if they found it on the shelves of their regular supermarket ("Suppose you are shopping in your familiar supermarket and see an offer for [premium item], shown below. How much would you be willing to pay for this product at this moment?”) (e.g., Gaeth et al. 1990). The sample consisted of 175 consumers who were reached online via snowball sampling and had a socio-demographic profile similar to that of the subjects in our main study. We discarded 22 of the 39 premiums because their perceived value was too high, too low, or too variable across respondents.

In a second pre-test, we asked 219 randomly selected members of an online research panel at the school of one of the authors to rate the 17 retained premiums' functional relatedness to the four categories on a seven-point semantic differential scale ("How likely are people to use [premium item] together with [product category]?”) (e.g., Aaker and Keller 1990). For each category, we finally selected one clearly unrelated and one clearly (and significantly more, $p<.01)$ related premium with very similar perceived values. In Table 2 , 
columns 7 to 12 , we give an overview of the selected premiums and their perceived values and relatedness scores.

\subsection{Determination of Price Cut Levels}

In each category, we determined three price cut levels (see the last three columns of Table 2). One of them, usually the middle one, equals the premium's perceived value. The two other levels were derived by adding or subtracting approximately $10 \%$ of the average regular price in the category. ${ }^{1}$ These three price cut levels allow us to estimate the effect of discount depth, which we use in section 7 to determine which (non-equivalent) price cut generates the same sales impact as a premium. In the shopping experiment, price cuts were always presented as absolute amounts.

\subsection{Survey Design}

The online survey consisted of three parts: initialization, actual purchase simulation, and concluding section. In the initialization stage, we screened respondents and gathered data needed for an individualized purchase simulation. Respondents had to be actively involved in buying groceries for their household and regularly shop in at least one of the four selected product categories. If these pre-requisites were met, we assigned respondents to two categories (or to one, if they regularly shopped in only one category). Respondents then provided details about their current inventory and average weekly consumption amounts for the categories to which they were assigned. We used this information to calculate a respondent's running inventory during the shopping simulation.

The simulation, a one-shot data collection, covered a fictitious period of seven consecutive weeks (i.e., shopping trips) during which respondents could make purchases in

\footnotetext{
${ }^{1}$ For margarine, the perceived premium value is high relative to the regular price of the private label. Therefore, we selected two additional price cut levels below the equivalent price cut (equivalent price cut minus 10 and $20 \%$ of the average regular price in the category).
} 
the assigned categories. Respondents were instructed to behave as they would in a real shopping environment and were told that they could also decide not to make a purchase in a given week. We used illustrations to explain the different aspects of the shopping environment step by step, including how to make a purchase and where to find product and promotional information.

In the beginning of each shopping week, we showed participants their running inventory, accounting for their previous (fictitious) purchase quantities and weekly consumption amounts. Next, we displayed a shelf with pictures of the SKUs making up the assortment along with their prices. Respondents could roll the mouse over the product's picture to open a pop-up window with further details on brand name, form, flavor, and size. In the boxes below the products, consumers had to indicate their purchase quantity, if nonzero. In weeks in which products were on promotion, we displayed a banner above the shelf with information about the promotion and, for premium promotions, a picture of the premium. When respondents held the mouse on the promotional banner, a pop-up window with more details (e.g., a bigger picture of the premium) opened up. In addition, we attached promotional signs to the promoted products on the shelves and highlighted the product's discounted price in red (for price promotions) or added "+ gift" to the price tag (for premium promotions). Figure 2 provides examples.

-- Insert Figure 2 about here --

To study the effects of the different promotions, we used a full-factorial design, yielding 10 possible brand-promotion combinations per category $(2$ brands $\times(2$ premiums + 3 price cuts)). Note that our assortments included several brands, but we put only two on promotion. During the seven-week simulation, we made sure there was always one promotion-free week per category while we alternately attached a promotion to either the national brand or the private label SKUs during the remaining six weeks. In other words, in 
each category, a respondent was exposed to a maximum of one promotion per week. We varied the promotions across respondents but made sure that a respondent neither saw the same promotion nor a promotion for the same brand in consecutive weeks.

The last part of the survey contained some perceptual measures among which respondents' perceived quality of the promoted brands. This manipulation check was successful in that the quality perceptions for the private label were systematically lower than those for the national brand (see the Appendix for details). Furthermore, we collected information on respondents' socio-demographics and usual purchase behavior (average interpurchase time, usual purchase amount, and choice shares for the different SKUs during the last twelve months, which we use as control variables in our models).

\subsection{Sample Characteristics}

11,704 randomly selected members of a commercial online research panel were invited to participate in the shopping simulation, with a chance to win one of several gift vouchers. $2,042(17.4 \%)$ passed the filtering questions (regarding responsibility for buying groceries and familiarity with buying in the studied categories, see previous section), and completed the survey. We retained 2,027 respondents after removing those whose reported usual weekly purchase amount and usual weekly consumption amount were too divergent. ${ }^{2}$ The sample composition (see Table 3) reflects the profile of West European shoppers (e.g., Sloot, Verhoef and Franses 2005).

\section{-- Insert Table 3 about here --}

To generate meaningful starting values for the inventory and purchase feedback variables (see Model section), we removed the first week of the simulation from the dataset. Model estimation is thus based on six purchase occasions per respondent in each of the

\footnotetext{
${ }^{2}$ More precisely, we divided the respondent's self-stated usual purchase amount by their self-stated usual interpurchase time (in weeks) to obtain the usual weekly purchase amount: we removed the respondent if this amount differed by more than three units from their self-stated usual weekly consumption amount.
} 
categories to which s/he was assigned. Table 4 presents the number of respondents and purchase occasions for the different categories as well as the incidence rates, choice shares, and average purchase quantities under promotion and non-promotion conditions. In general, price cuts increase the incidence rate and the focal SKUs' average choice share and purchase quantity. Premiums, in contrast, only appear effective at the incidence and choice level, not at the quantity level. Evidently, we must exercise caution when interpreting these numbers as they do not account for possibly confounding factors. We therefore estimate a model of consumer purchase behavior to test our hypotheses.

-- Insert Table 4 about here --

\section{Model}

We formulate a joint model for consumers' incidence/choice and quantity decisions, using a modeling framework similar to that of Andrews and Currim (2009). It includes a nested logit structure for purchase incidence and brand choice, and a zero-truncated Poisson model for purchase quantity. We model consumers' decisions at the SKU level, because the promotions usually involved only a subset of the SKUs belonging to a single brand (Fader and Hardie 1996). To accommodate unobserved consumer heterogeneity, we model all parameters as normally distributed random coefficients (Train 2009). Furthermore, in line with Andrews and Currim (2009), we allow for interdependencies across the decision levels by including cross-sectional and contemporaneous error correlations. In each category, we jointly calibrate the models through simulated maximum likelihood with 100 quasi-random Halton draws from the coefficient distributions (Train 2009; Foubert and Gijsbrechts 2007).

\subsection{Purchase Incidence and Brand Choice Decision}


In line with much other research on purchase behavior (e.g., Silva-Risso, Bucklin and Morrison 1999; Van Heerde, Gupta and Wittink 2003; Ailawadi et al. 2007; Bezawada and Pauwels 2013), we use a nested logit framework in which choice and incidence are integrated decisions. In this framework, the category incidence probability is a binomial logit model and the SKUs' choice probabilities take a multinomial logit form. We write the probability that consumer $\mathrm{h}$ buys in the category in week $\mathrm{t}$ as:

$$
\mathrm{P}_{\mathrm{ht}}^{\text {incidence }}=\frac{\exp \left(\alpha_{\mathrm{h}} \mathrm{Y}_{\mathrm{ht}}^{\prime}+\mu_{\mathrm{h}} \mathrm{INCV} \mathrm{ht}_{\mathrm{ht}}+\tau_{\mathrm{t}}\right)}{1+\exp \left(\alpha_{\mathrm{h}} \mathrm{Y}_{\mathrm{ht}}^{\prime}+\mu_{\mathrm{h}} \mathrm{INCV_{ht }}+\tau_{\mathrm{t}}\right)}
$$

with

$$
\begin{array}{ll}
Y_{\mathrm{ht}} & \text { a row vector of consumer- and week-specific variables; } \\
\mathrm{INCV}_{\mathrm{ht}} & \text { "inclusive value" for consumer } \mathrm{h} \text { in week } \mathrm{t} \text {, computed as } \\
& \ln \left(\sum_{\mathrm{i}} \exp \left(\mathrm{V}_{\mathrm{hit}}\right)\right) \text { where } \mathrm{V}_{\text {hit }} \text { refers to the structural utility of SKU i for } \\
& \text { consumer } \mathrm{h} \text { in week } \mathrm{t} \text { in the brand choice model; } \\
& \text { normally distributed consumer-specific coefficients, with } \alpha_{\mathrm{h}} \text { a row } \\
\alpha_{\mathrm{h}} \text { and } \mu_{\mathrm{h}} \quad & \text { vector and } \mu_{\mathrm{h}} \text { a scalar; and } \\
& \text { a normally distributed time-specific error term. }
\end{array}
$$

The vector of control variables $\mathrm{Y}_{\mathrm{ht}}$ includes the consumer's mean-centered inventory and the self-stated usual inter-purchase time (e.g., Ailawadi et al. 2007; Silva-Risso, Bucklin and Morrison 1999). We find a consumer's inventory in week $t$ as $\max (0$, inventory in week $(\mathrm{t}-$ 1) + actual amount bought in week ( $\mathrm{t}-1)$ - self-reported usual weekly consumption). The inclusive value $\mathrm{INCV}_{\mathrm{ht}}$ represents the expected maximum utility of buying in the category and is affected by shifts in the structural utilities $\mathrm{V}_{\text {hit }}$ of the individual SKUs, for example due to the presence of sales promotions (Bucklin and Lattin 1991). $\mu_{\mathrm{h}}$, the so-called scale parameter, quantifies the extent to which these utility shifts influence the consumer's purchase incidence decision. $\mu_{\mathrm{h}}$ should take values between 0 and 1 to be in line with random utility theory (Train 2009). Finally, in line with Andrews and Currim (2009), we include an 
unobserved common (i.e., across consumers) demand shock $\tau_{t}$, to incorporate contemporaneous correlation with the quantity model (see below). ${ }^{3}$

The choice probability of consumer $\mathrm{h}$ for SKU $\mathrm{i}$ in week $\mathrm{t}$ is written as follows:

$$
\mathrm{P}_{\text {hit }}^{\text {choice }}=\frac{\exp \left(\mathrm{V}_{\mathrm{hit}}\right)}{\sum_{\mathrm{j}} \exp \left(\mathrm{V}_{\mathrm{hjt}}\right)}
$$

$V_{\text {hit }}$, the structural utility, has the following form:

$$
\begin{aligned}
V_{\text {hit }}= & \beta_{1 \mathrm{~h}} \mathrm{X}_{\text {hit }}^{\prime}+\left(\beta_{2 \mathrm{~h}} \text { PREM }_{\text {hit }}+\beta_{3 \mathrm{~h}} \mathrm{PREM}_{\text {hit }} \times \mathrm{REL}_{\mathrm{hit}}+\beta_{4 \mathrm{~h}} \mathrm{PREM}_{\mathrm{hit}} \times \mathrm{NB}_{\text {hit }}\right) \\
& +\left(\beta_{5 \mathrm{~h}} \text { DISC }_{\text {hit }}+\beta_{6 \mathrm{~h}} \text { DISC }_{\text {hit }} \times \mathrm{NB}_{\text {hit }}\right)
\end{aligned}
$$

with

$$
\begin{aligned}
& \mathrm{X}_{\text {hit }} \quad \text { row vector of SKU-, consumer-, and week-specific variables; } \\
& \text { PREM }_{\text {hit }} \text { dummy variable indicating whether there was a premium for SKU i } \\
& \text { available to consumer } \mathrm{h} \text { in week } \mathrm{t} \text {; } \\
& \text { REL hit }_{\text {mean-centered dummy variable indicating whether the premium for }} \\
& \text { SKU i available to consumer } \mathrm{h} \text { in week } \mathrm{t} \text { was functionally related to the } \\
& \text { category; } \\
& \mathrm{NB}_{\text {hit }} \quad \text { mean-centered dummy variable indicating whether the promoted SKU } \\
& \mathrm{i} \text { available to consumer } \mathrm{h} \text { in week } \mathrm{t} \text { belonged to the national brand; } \\
& \text { DISC }_{\text {hit }} \text { depth (in Euros) of the price cut for SKU i available to consumer } h \text { in } \\
& \text { week } \mathrm{t} \text {, divided by the premium-equivalent discount; and } \\
& \beta_{1 \mathrm{~h}}, \ldots, \beta_{6 \mathrm{~h}} \quad \text { normally distributed consumer-specific coefficients, with } \beta_{1 \mathrm{~h}} \text { a row } \\
& \text { vector and } \beta_{2 \mathrm{~h}}, \ldots, \beta_{6 \mathrm{~h}} \text { scalars. }
\end{aligned}
$$

The vector of control variables $\mathrm{X}_{\mathrm{hit}}$ contains brand-, type-, and flavor-specific dummy

variables, a loyalty variable representing the consumer's self-stated normal choice shares for

\footnotetext{
${ }^{3}$ Note that, unlike Andrews and Currim (2009), we do not include additional brand-specific common demand shocks at the choice level. Given the relatively large number of SKUs (at least in the cereals category), this would make the model unwieldy. Moreover, because of our experimental setting, it is very unlikely that we ignored any brand- and time-specific phenomena (e.g., unobserved promotions). Instead, any time-specific error (e.g., respondent fatigue) is likely to be shared by all SKUs, and is thus captured by $\tau_{\mathrm{t}}$ at the incidence level.
} 
the different SKUs, and a purchase feedback dummy variable which equals 1 if the consumer bought the same SKU on the previous purchase incidence (Bucklin and Lattin 1991; Fader and Hardie 1996).

The two bracketed terms capture the impact of the premiums and price cuts, respectively. Coefficients $\beta_{2 h}$ till $\beta_{6 h}$ enable us to test our hypotheses at the brand choice level. As noted before, these effects carry through to the purchase incidence level via the

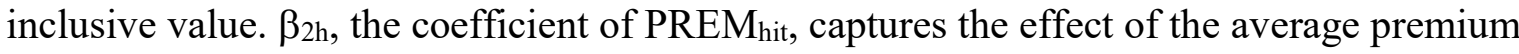
promotion because $\mathrm{REL}_{\text {hit }}$ and $\mathrm{NB}_{\text {hit }}$ are mean-centered across observations in which there was a promotion (e.g., Brüggen, Foubert and Gremler 2011). Similarly, $\beta_{5 \mathrm{~h}}$, the coefficient of DISC $_{\text {hit }}$, represents the average effect, across private label and national brand, of the premium-equivalent price cut. $\mathrm{DISC}_{\text {hit }}$ is computed as the discount divided by the premiumequivalent price cut, such that it is 1 when the discount equals the premium-equivalent price cut. The coding of our variables implies that we can directly compare $\beta_{2 h}$ and $\beta_{5 h}$ to investigate comparative premium effectiveness, i.e., the main effects of premiums relative to those of price cuts. At the same time, it also keeps the interpretation of the moderators' coefficients intuitive. $\beta_{3 \mathrm{~h}}$ captures the effect of the switch from an unrelated to a functionally related premium. Furthermore, by comparing $\beta_{4 \mathrm{~h}}$ and $\beta_{6 \mathrm{~h}}$, we can assess the extent to which premiums become less or more effective compared to price cuts, when the promoted products belong to a national brand rather than a private label. In Table 5, we summarize how the model parameters enable us to test our hypotheses.

$$
\text { -- Insert Table } 5 \text { about here -- }
$$

\subsection{Quantity Decision}


Given purchase incidence and choice of SKU i, we model the probability that consumer h buys $\mathrm{q}_{\text {hit }}$ units of SKU $\mathrm{i}$ in week $\mathrm{t}$ using a Poisson model with truncation of the zero outcome (e.g., Andrews and Currim 2009; Foubert and Gijsbrechts 2007):

$$
\mathrm{P}_{\text {hit }}^{\text {quantity }}\left(\mathrm{q}_{\text {hit }}\right)=\frac{\exp \left(-\lambda_{\text {hit }}\right) \lambda_{\text {hit }}{ }^{\mathrm{q}_{\text {hit }}}}{\mathrm{q}_{\text {hit }} !\left(1-\exp \left(-\lambda_{\text {hit }}\right)\right)}
$$

where $\lambda_{\text {hit }}$ is consumer h's purchase rate for SKU i in week t. We write $\lambda_{\text {hit }}$ as an exponential function:

$$
\begin{aligned}
\lambda_{\text {hit }}= & \exp \left(\gamma_{1 \mathrm{~h}} \mathrm{Z}_{\mathrm{hit}}^{\prime}+\left(\gamma_{2 \mathrm{~h}} \mathrm{PREM}_{\mathrm{hit}}+\gamma_{3 \mathrm{~h}} \mathrm{PREM}_{\mathrm{hit}} \times \mathrm{REL}_{\mathrm{hit}}+\gamma_{4 \mathrm{~h}} \mathrm{PREM}_{\mathrm{hit}} \times \mathrm{NB}_{\mathrm{hit}}\right)+\right. \\
& \left.\left(\gamma_{5 \mathrm{~h}} \mathrm{DISC}_{\mathrm{hit}}+\gamma_{6 \mathrm{~h}} \text { DISC }_{\text {hit }} \times \mathrm{NB}_{\mathrm{hit}}\right)+\theta_{\mathrm{t}}\right)
\end{aligned}
$$

with

$$
\begin{array}{ll}
Z_{\mathrm{hit}} & \text { a row vector of SKU-, consumer-, and week-specific variables; } \\
\gamma_{1 \mathrm{~h}}, \ldots, \gamma_{6 \mathrm{~h}} & \text { normally distributed consumer-specific coefficients, with } \gamma_{1 \mathrm{~h}} \text { a row } \\
& \text { vector and } \gamma_{2 \mathrm{~h}}, \ldots, \gamma_{6 \mathrm{~h}} \text { scalars; and } \\
\theta_{\mathrm{t}} & \text { a normally distributed time-specific error term. }
\end{array}
$$

$Z_{\text {hit }}$ includes brand-, type-, and flavor-specific dummy variables, the consumer's meancentered inventory (as in Equation 1), the loyalty variable (as in Equation 3), and the consumer's self-stated usual purchase amount. We use the same variables as before to assess promotion effects at the quantity level and test our hypotheses in a similar way (see Table 5).

To avoid bias in the response parameters, we model cross-sectional and contemporaneous interdependencies between the decision levels (Andrews and Currim 2009). We allow for correlation between the brand-specific intercepts in the quantity model and the corresponding intercepts in the incidence/choice model. In addition, the quantity model includes a time-specific error term $\theta_{\mathrm{t}}$ (shared by all SKUs) which we allow to be correlated with the time-specific error term $\tau_{\mathrm{t}}$ in the incidence model. 


\section{Results}

Table 6 presents the estimates of the means and standard deviations of the parameter distributions in each product category (significant parameters in bold, standard errors in brackets). The effects of the control variables are mostly in line with patterns observed in real-life purchase data (e.g., Ailawadi et al. 2007; Silva-Risso, Bucklin and Morrison 1999), corroborating the ecological validity of our study. In all four categories, the incidence probability is lower for respondents with larger inventories or longer usual inter-purchase times. Also, in all four categories, the brand choice probability increases when the consumer has bought the same SKU in the previous simulated shopping trip (purchase feedback) or buys the SKU on a regular basis (loyalty). Furthermore, for most categories, we find the expected negative effects of inventory and positive effects of loyalty on the quantity decisions ${ }^{4}$ Finally, in line with random utility theory, the mean scale parameters in the incidence model (Equation 1) vary between 0 and 1 (Train 2009).

$$
\text { -- Insert Table } 6 \text { about here -- }
$$

Below, we first look at the main effects of premiums compared to those of price cuts, then discuss how the moderators influence this comparative premium effectiveness, and finally present several robustness checks. The estimated standard deviations in Table 6 suggest that consumer response to premium promotions and price cuts is rather homogeneous. Therefore, we focus on the reactions of the average consumer, as reported in the columns labeled "Mean." Effects that are stated to be significant, are so at the $p<.05$ level (two-sided).

\subsection{Comparative Premium Effectiveness}

\footnotetext{
${ }^{4}$ One somewhat surprising result is the significant positive mean impact $(p<.01)$ of inventory on consumers' quantity decisions in the orange juice category. This may be due to cyclic buying whereby consumers consistently purchase large amounts in certain periods and nothing or much less in other periods.
} 
To compare the main effects of premiums and price cuts $\left(\mathrm{H}_{1}\right)$, we examine the coefficients of PREM and DISC. Table 6 shows that the mean impact of a premium on choice and quantity is consistently smaller than that of the corresponding price cut. In fact, at the quantity level, the mean impact of a premium is typically small or even non-significant. Using t-tests (see Table 5), we find that the difference between the mean coefficients of PREM and DISC is significant for orange juice, margarine, and milk, at the choice as well as at the quantity level. It is non-significant for cereals, indicating that premiums are as effective as equivalent price cuts in this category. A possible explanation could be the more hedonic nature of the cereal category. The benefit congruency framework by Chandon, Wansink and Laurent (2000) suggests that hedonic promotions like premiums gain effectiveness in hedonic categories, while utilitarian promotions like price cuts are more effective in utilitarian categories. Our respondents indicated that they perceived cereals as the most hedonic and least utilitarian among the four product categories. ${ }^{5}$ Thus, in partial support of hypotheses $\mathrm{H}_{1 \mathrm{a}}$ and $\mathrm{H}_{1 \mathrm{~b}}$, a premium tends to increase consumers' choice probabilities and purchase quantities less than an equivalent price cut.

\subsection{Impact of Moderators on Comparative Premium Effectiveness}

Related versus Unrelated Premiums. In Table 6, the coefficients for PREM $\times$ REL capture the effect of the shift from an unrelated to a functionally related premium on comparative premium effectiveness. We find that the mean coefficient is non-significant throughout, except in the juice category at the choice level. Thus, contrary to $\mathrm{H}_{2 \mathrm{a} / \mathrm{b}}$, using a functionally related as opposed to an unrelated premium typically does not bring the premium effect any closer to that of the equivalent price cut. For orange juice, where functional relatedness does play a role, the mean impact on choice of the related premium remains significantly below

\footnotetext{
${ }^{5}$ We measured this with rating scales at the end of the survey. Details are available upon request.
} 
that of the equivalent price cut (1.84 versus 2.89$){ }^{6}$ This result is in contrast with previous research which shows that related premiums produce more favorable attitudes and purchase intentions than unrelated ones (e.g., Harlam et al. 1995; Jones 2008; Jones 2015). This may be because we study purchase behavior in a realistic environment with a large number of products in each category. In such a situation, a promotion needs to stand out to draw consumers' attention, which is at least as easy with an unrelated premium (e.g., Gijsenberg 2014; Mazodier and Quester 2014).

Private Label versus National Brand. To test whether the premium's comparative effectiveness decreases when the promoted SKUs belong to a national brand as opposed to a private label, we compare the mean coefficients of DISC $\times$ NB and PREM $\times$ NB. At the choice level, the mean coefficient of DISC $\times$ NB is significantly higher than the mean coefficient of PREM $\times$ NB for orange juice, margarine, and milk, but does not differ significantly for cereals (see Table 5). These results lend partial support to $\mathrm{H}_{3 \mathrm{a}}$ and suggest that asymmetric brand switching - the phenomenon whereby promoted national brands attract more private label buyers than promoted private labels attract national brand buyers (Sivakumar and Raj 1997) - is less likely to occur for premiums than for price cuts. At the quantity level, the difference between the coefficients of DISC $\times$ NB and PREM $\times$ NB is non-significant in all four categories (see Table 5). Hence, we do not find support for $\mathrm{H}_{3 \mathrm{~b}}$. In fact, almost all interaction coefficients in the quantity model are insignificant, indicating that the average consumer is not more likely to stock up on a promoted national brand than on a promoted private label. Possibly, consumers who usually buy the private label want to avoid the risk of being stuck with excess inventory of an unfamiliar national brand (irrespective of whether the product is price- or premium-promoted).

\footnotetext{
${ }^{6}$ The mean impact of the related premium is found as $\beta_{2}+\beta_{3} \times .50=1.56+.56 \times .50$, where .50 is the value of the (mean-centered) variable REL when the premium is related.
} 


\subsection{Robustness Checks}

We conducted several checks to test the robustness of our results. First, we checked whether our significant coefficient-based hypotheses tests can be replicated on the basis of the percentage changes in choice probabilities and purchase quantities. To calculate these percentage changes, we simulated purchase behavior for each consumer in our dataset, in response to the premium promotions and the equivalent price cuts from our shopping experiment. We then computed the percentage changes in the average choice probability and purchase quantity for the promoted items and retested our hypotheses on comparative premium effectiveness and the role of the moderators. These additional tests mostly corroborate our earlier insights. The Web Appendix to this paper (part A) describes the tests and results in detail.

Second, one of our findings is that a premium promotion generates substantially lower purchase effects than a price cut, even though the premium as a stand-alone item is judged equivalent to the price cut. One potential reason is that the value of a premium decreases in a promotional context. To support this insight, we ran an additional study in which we assessed the difference in willingness-to-pay (WTP) when the premium item is presented alone (identical to what we did in our pre-tests to determine equivalence) versus when it is presented as a promotional incentive, combined with a promoted product (similar to what consumers saw in the purchase simulation study). 173 university students evaluated the four related premiums from our main study. They were randomly assigned to an experimental group, in which they saw these premiums either as stand-alone items or as free gifts, bundled with a product (private label or national brand). We asked how much they would be willing to pay for each premium if it were for sale. The WTP was always significantly higher when the premium was offered separately than when it was part of a bundle $(p<.01)$. Thus, 
offering an item as a free gift leads to devaluation of that item, in line with $\mathrm{H}_{1}$. We provide more details on this additional study in the Web Appendix (part B).

Third, we address the concern that our model may not be flexible enough to capture differences in the promotions' effects at the purchase incidence level. We estimated an alternative model, in which we added separate promotion variables at the incidence level to account for any effects above and beyond those captured by the inclusive value. We find no additional significant differences between premiums and price cuts at the incidence level. Moreover, the promotion coefficients at the choice and quantity levels show virtually the same patterns as those reported in Table 5. These results underscore that the nested logit model is adequate to assess comparative premium effectiveness.

Fourth, we examined whether promotion effectiveness is influenced by previous promotions. We extended our model by adding interactions between, on the one hand, the premium and price cut variables and, on the other hand, two dummy variables indicating whether there was a premium promotion or a price cut in the previous week. Out of the 32 interaction coefficients (four at the choice level and four at the quantity level, in each category), only five are significant. Moreover, our key results remain largely unaffected. Additional details on the last two robustness checks are available upon request.

\section{Aggregate Sales Effects and Cost Considerations}

Our estimation results show that premiums lead to weaker purchase effects than equivalent price cuts but that the size of the difference depends on the promoted brand, and to some extent on the category under consideration. In this section, we consider the implications in terms of aggregate sales effects. Furthermore, we analyze how large a premium's cost advantage has to be to compensate for a smaller sales impact and make the premium's profit contribution larger than that of a price cut. 


\subsection{Unit Sales Impact of Premiums and Equivalent Price Cuts}

On the basis of the simulated purchase behavior from our first robustness check (see section 6.3 and Web Appendix, part A), we computed the promotions' impact on aggregate unit sales of the promoted SKUs and of the category to which these SKUs belong. Table 7 reports the results for the promoted SKUs (panel a) and the category (panel b) as percentage increases in sales, relative to the scenario without a promotion. Because our estimation results did not reveal any systematic role of the premium's functional relatedness to the category, we do not report separate unit sales effects for related and unrelated premiums but, instead, show their average impact. A first interesting point is that the price cut effects in panel a appear credible: they correspond to price elasticities between -3 and $-9,{ }^{7}$ which is in line with previous literature (e.g., Narasimhan, Neslin and Sen 1996; Bijmolt, van Heerde and Pieters 2005).

$$
\text { -- Insert Table } 7 \text { about here -- }
$$

While premiums increase sales of the promoted SKUs considerably (panel a), their impact at the category level is typically small (panel b). Importantly, premiums systematically generate lower SKU and category sales increases than equivalent price cuts. In line with our estimation results, this difference is small for cereals but can be quite large in other (more utilitarian) categories. For example, for a national brand in the milk category, SKU sales increase by $46.86 \%$ in response to the premium promotion, but by $172.00 \%$ in response to an equivalent price cut. Like before, the differences between premiums and price cuts are typically larger for national brands than for private labels.

\subsection{The Premium Indifference Cost}

\footnotetext{
${ }^{7}$ To obtain the elasticities, we divide the percentage changes in sales by the underlying percentage change in the price of the promoted SKUs.
} 
The previous section illustrates that premiums are less effective at increasing unit sales than equivalent price cuts. However, to asses a promotion's profit contribution, managers need to consider costs too. A premium may cost less than the value that consumers ascribe to it and, thus, than the equivalent price cut, such that a premium may be more profitable than a price cut. Therefore, we investigate how much the studied premiums can maximally cost per unit, to be preferable to a price cut. We call this amount the premium's "indifference cost" and compute it as the price cut that generates the same sales impact as the premium. ${ }^{8}$ If a premium costs less than its indifference cost, it is more cost-effective than the equivalent price cut. We compute the indifference cost twice: once as the price cut that yields the same $S K U$ sales and once as the price cut that generates the same category sales. To make indifference costs comparable across categories, they are expressed relative to the premium's value as measured in our first pre-test (see Table 2). In Table 8, we report these "indifference cost-value ratios." Like before, we average over related and unrelated premiums.

\section{-- Insert Table 8 about here --}

The results show that premiums entail risks as well as opportunities, in particular for retailers. On the one hand, we find that retailers, who often focus on category sales, face much tighter premium cost constraints than manufacturers who are mainly interested in sales of their promoted national brand. For example, a national brand manufacturer in the margarine category should prefer the premium to a price cut as long as the premium's cost is less than $34.48 \%$ of its perceived value. A retailer who aims at category sales, however, should not contribute more than $6.09 \%$ of the premium value because premiums are less effective at the category level (see Table 7).

On the other hand, the premium indifference costs are systematically higher for private labels than for national brands. For example, in the orange juice category, a national

\footnotetext{
${ }^{8} \mathrm{We}$ used a trial-and-error procedure that exploits the estimated linear price cut effect to find the price cut that yields the same sales outcome as the premium.
} 
brand manufacturer should not use a premium that costs more than $38.77 \%$ of its perceived value, while, for a private label, marketers can afford a premium cost of up to $54.45 \%$ of the premium value. Thus, even when a price cut causes a larger boost in category sales, a premium promotion may be more cost-effective at shifting sales from manufacturer brands to the retailer's private labels, which often offer a higher profit margin.

\section{Conclusions}

Using data from a large computer-simulated shopping experiment, we compare the effects of premiums and price cuts on consumers' purchase decisions. To ensure a fair comparison of the two promotion types, we establish their equivalence on the basis of the value of the premium when it is offered in isolation. While previous research demonstrates that premiums may lead to more favorable subjective consumer reactions than price cuts (e.g., Darke and Chung 2005), we find that premium promotions tend to generate smaller purchase effects than equivalent price cuts. Especially a premium's quantity effects are typically small or insignificant. These findings may be driven by mechanisms that only manifest themselves with purchase decisions. For example, compared to a price cut, a premium may be perceived as less fungible or more manipulative and therefore provoke stronger reactance such that consumers are more inclined not to choose the promoted product (Brehm 1966). Furthermore, in comparison with price cuts, premiums are less likely to induce quantity acceleration because the marginal value of a gift declines with each additional unit.

Although premiums generally lead to smaller purchase effects than equivalent price cuts, we find that, at the choice level, a premium's comparative effectiveness is typically higher for private labels than for national brands. For national brands, price cuts, unlike premiums, enjoy a very strong brand switching effect, because a lower price makes national brands affordable to price-sensitive consumers. Interestingly, a premium's comparative 
effectiveness appears largely independent of its functional relatedness to the category. This finding underscores that consumers are attracted by a premium because of the experience of receiving a gift or because of the premium's intrinsic value, both of which do not depend on the functional relationship between premium and product category. In fact, in a promotion context, it is also very important to stand out and attract shoppers' attention, and this is at least as easy with an unrelated premium (Gijsenberg 2014; Gedenk, Hoffmann and Fantapié Altobelli 2013; Mazodier and Quester 2014).

Our computations indicate that, in circumstances in which the sales impact of a premium is not too far below that of the equivalent price cut, the premium may be more profitable because its cost to the company is typically below its perceived value to the consumer (and thus below the equivalent price cut). This cost advantage may be large enough to compensate for any fixed costs related to planning, coordination, or packaging. Because of the substantial choice effects yet weak quantity effects, a premium can be particularly rewarding when the focus is on SKU or brand performance, rather than on category performance. This finding may suggest that only manufacturers can benefit, but premiums do offer opportunities for retailers too: especially for private labels (which often have higher profit margins), premiums may be more cost-effective than price cuts to attract sales from competing brands.

Our general finding that price cuts yield greater purchase effects is in line with current managerial practice. An analysis of store flyer data teaches us that price cuts are far more common than premium promotions. The database, which was provided to us by a store flyer monitoring company, contains three years of store flyer information for all major brick-andmortar retailers in the focal country. It includes 2,035 ads featuring either a price cut or a premium in one of the four studied categories. Table 9 shows how these ads are distributed across categories and promotion types. Overall, 19\% of the studied ads involve premium 
promotions. Thus, price cuts dominate, but managers sometimes do take premiums into consideration. Our findings help them to determine under which conditions they are indeed better off using premium promotions.

\section{-- Insert Table 9 about here --}

A few factors that are not part of our analysis may further affect managers' interest in premium promotions. Premium promotions and price cuts may differ in how strongly they increase store traffic, which is important for retailers. On the one hand, since premiums appear less frequently in store flyers, they may draw more attention, and thus be more effective at building store traffic than price cuts. On the other hand, price cuts may increase store traffic more because they are fungible and provide a stronger incentive to switch stores. A factor that may influence a manufacturer's interest in premium promotions is retailer passthrough. While retailer pass-through rates for (manufacturer-initiated) price cuts are often below 100\% (Besanko, Dubé and Gupta 2005), pass-through of premium promotions is typically high: due to high awareness of premium promotions, consumers may consider switching to competing stores if they detect retailer opportunism (Kumar, Rajiv and Jeuland 2001; Walters 1989). Since premiums can only be passed on in their entirety or not at all, pass-through rates of $100 \%$ are more likely for premium promotions than for price cuts. For manufacturers, this increases a premium promotion's relative cost-effectiveness. At the same time, if a premium promotion results in a higher profit contribution for the manufacturer but not for the retailer, retailers can demand trade deals to compensate for their loss.

Various issues remain to be addressed in future studies. First, the generalizability of our insights can be enhanced in several ways. For example, while we included eight distinct premiums, future work could verify whether our results generalize across many more different premiums. Also, our research could be repeated for non-FMCG categories. Furthermore, it is possible that the promotions attracted more attention than would have been 
the case in a real store. Although this is unlikely to change the comparative effectiveness of premiums and price cuts, future research could replicate our work with real purchase decisions.

Second, the use of real purchase data would also enable us to better accommodate purchase dynamics, such as stockpiling and variety-seeking. Importantly, the differences in dynamics between premiums and price cuts may improve the comparative performance of premium promotions. For example, most of the large quantity effects triggered by price cuts may be due to forward-buying. Also, the impact of a premium on consumers' reference prices may be less detrimental than that of a price cut, such that consumers' purchase behavior remains more stable after a premium promotion than after a price cut.

Third, premium promotions are sometimes offered under stricter purchase conditions with consumers having to pay a small amount or buy several units of the promoted brand, at once or spread over time, to receive the premium. Also, premiums may be samples of another product or make up a collection of related gifts such as a series of photographs of soccer players (cf. instant reward program, Minnema, Bijmolt and Non 2016). Future work could examine these other forms of premium promotion.

Finally, while our hypothesis tests reveal several clear response patterns, the results are sometimes mixed. This suggests that other drivers of comparative premium effectiveness may be at work. For example, in the cereals category, the performance of premiums approached that of price cuts. It would be interesting to explicitly assess the role of the category's hedonic versus utilitarian nature and examine whether, in outspokenly hedonic categories (e.g., confectionery), premiums can actually outperform equivalent price cuts. We encourage further research on other potential moderators. 


\section{References}

Aaker, David A. and Kevin Lane Keller (1990). "Consumer Evaluations of Brand Extensions." Journal of Marketing 54 (1), 27-41.

Ailawadi, Kusum L., Karen Gedenk, Christian Lutzky, and Scott A. Neslin (2007). "Decomposition of the Sales Impact of Promotion-Induced Stockpiling." Journal of Marketing Research 44 (3), 450-67.

Ailawadi, Kusum L. and Sunil Gupta (2014). "Sales Promotions." Pp 463-97 in The History of Marketing Science, Russell S. Winer and Scott A. Neslin (eds). Singapore: World Scientific Publishing.

Ailawadi, Kusum L. and Bari A. Harlam (2009). "Retailer Promotion Pass-Through: A Measure, Its Magnitude, and Its Determinants." Marketing Science 28 (4), 782-91.

Ailawadi, Kusum L., Bari A. Harlam, Jacques César, and David Trounce (2006). "Promotion Profitability for a Retailer: The Role of Promotion, Brand, Category, and Store Characteristics." Journal of Marketing Research 43 (4), 518-35.

Andrews, Rick L. and Imran S. Currim (2009). "Multi-Stage Purchase Decision Models: Accommodating Response Heterogeneity, Common Demand Shocks, and Endogeneity Using Disaggregate Data." International Journal of Research in Marketing 26 (3), 197-206.

Arora, Neeraj and Ty Henderson (2007). "Embedded Premium Promotion: Why It Works and How to Make It More Effective." Marketing Science 26 (4), 514-31.

Bawa, Kapil and Robert Shoemaker (2004). "The Effects of Free Sample Promotions on Incremental Brand Sales." Marketing Science 23 (3), 345-63.

Bell, David R., Jeongwen Chiang, and V. Padmanabhan (1999). "The Decomposition of Promotional Response: An Empirical Generalization." Marketing Science 18 (4), 50426.

Besanko, David, Jean-Pierre Dubé, and Sachin Gupta (2005). "Own-Brand and Cross-Brand Retail Pass-Through." Marketing Science 24 (1), 123-37.

Bezawada, Ram and Koen Pauwels (2013). "What Is Special About Marketing Organic Products? How Organic Assortment, Price, and Promotions Drive Retailer Performance." Journal of Marketing 77 (1), 31-51.

Bijmolt, Tammo H.A., Harald J. van Heerde, and Rik G.M. Pieters (2005). "New Empirical Generalizations on the Determinants of Price Elasticity." Journal of Marketing Research 42 (2), 141-56.

Blattberg, Robert C. and Kenneth J. Wisniewski (1989). "Price-Induced Patterns of Competition." Marketing science 8 (4), 291-309.

Brehm, Jack W. (1966). A Theory of Psychological Reactance. New York: Academic Press.

Breugelmans, Els, Katia Campo, and Els Gijsbrechts (2006). "Opportunities for Active Stock-out Management in Online Stores: The Impact of the Stock-out Policy on Online Stock-out Reactions." Journal of Retailing 82 (3), 215-28.

Brüggen, Elisabeth C., Bram Foubert, and Dwayne D. Gremler (2011). "Extreme Makeover: Short- and Long-Term Effects of a Remodeled Servicescape." Journal of Marketing 75 (5).

Bucklin, Randolph E. and Sunil Gupta (1992). "Brand Choice, Purchase Incidence, and Segmentation: An Integrated Modeling Approach." Journal of Marketing Research 29 (2), 201-15.

Bucklin, Randolph E. and James M. Lattin (1991). "A Two-State Model of Purchase Incidence and Brand Choice." Marketing Science 10 (1), 24-39. 
Buil, Isabel, Leslie de Chernatony, and Teresa Montaner (2013). "Factors Influencing Consumer Evaluations of Gift Promotions." European Journal of Marketing 47 (3/4), 574-95.

Burke, Raymond R., Bari A. Harlam, Barbara E. Kahn, and Leonard M. Lodish (1992). "Comparing Dynamic Consumer Choice in Real and Computer-Simulated Environments." Journal of Consumer Research 19 (1), 71-82.

Campo, Katia, Els Gijsbrechts, and Fabienne Guerra (1999). "Computer Simulated Shopping Experiments for Analyzing Dynamic Purchasing Patterns: Validation and Guidelines." Journal of Empirical Generalizations in Marketing Science 4, 22-61.

Campo, Katia, Els Gijsbrechts, and Patricia Nisol (2000). "Towards Understanding Consumer Response to Stock-Outs." Journal of Retailing 76 (2), 219-42.

Chandon, Pierre, Brian Wansink, and Gilles Laurent (2000). "A Benefit Congruency Framework of Sales Promotion Effectiveness." Journal of Marketing 64 (4), 65-81.

Chandran, Sucharita and Vicki G. Morwitz (2006). "The Price of "Free"-Dom: Consumer Sensitivity to Promotions with Negative Contextual Influences." Journal of Consumer Research 33 (3), 384-92.

Chang, Chingching (2009). "Effectiveness of Promotional Premiums: The Moderating Role of Affective State in Different Contexts." Psychology \& Marketing 26 (2), 175-94.

Chou, Hsuan-Yi and Nai-Hwa Lien (2012). "The Effects of Incentive Types and Appeal Regulatory Framing in Travel Advertising." The Service Industries Journal 32 (6), 883-97.

d'Astous, Alain and Isabelle Jacob (2002). "Understanding Consumer Reactions to PremiumBased Promotional Offers." European Journal of Marketing 36 (11/12), 1270-86.

d'Astous, Alain and Valerie Landreville (2003). "An Experimental Investigation of Factors Affecting Consumers' Perceptions of Sales Promotions." European Journal of Marketing 37 (11/12), 1746-61.

Darke, Peter R. and Cindy M.Y. Chung (2005). "Effects of Pricing and Promotion on Consumer Perceptions: It Depends on How You Frame It." Journal of Retailing 81 (1), 35-47.

Fader, Peter S. and Bruce G. S. Hardie (1996). "Modeling Consumer Choice among Skus." Journal of Marketing Research 33 (4), 442-52.

Foubert, Bram and Els Gijsbrechts (2007). "Shopper Response to Bundle Promotions for Packaged Goods." Journal of Marketing Research 44 (4), 647-62.

--- (2016). "Try It, You'll Like It — or Will You? The Perils of Early Free-Trial Promotions for High-Tech Service Adoption." Marketing Science 35 (5), 810-26.

Gaeth, Gary J., Irwin P. Levin, Goutam Chakraborty, and Aron M. Levin (1990). "Consumer Evaluation of Multi-Product Bundles: An Information Integration Analysis." Marketing Letters 2 (1), 47-57.

Gedenk, Karen, Sönke Hartmann, and Tim Schulze (2000). "Die Wirkung Von Produktzugabe -Ein Conjoint-Experiment-." Zeitschrift für Betriebswirtschaft 12.

Gedenk, Karen, Sascha Hoffmann, and Claudia Fantapié Altobelli (2013). "Premium Promotions: Do They Work, and What Drives Their Effectiveness?" Working Paper.

Gedenk, Karen and Scott A. Neslin (1999). "The Role of Retail Promotion in Determining Future Brand Loyalty: Its Effect on Purchase Event Feedback." Journal of Retailing $75(4), 433$.

Gijsenberg, Maarten J. (2014). "Going for Gold: Investigating the (Non)Sense of Increased Advertising around Major Sports Events." International Journal of Research in Marketing 31 (1), 2-15. 
Harlam, Bari A, Aradhna Krishna, Donald R Lehmann, and Carl Mela (1995). "Impact of Bundle Type, Price Framing and Familiarity on Purchase Intention for the Bundle." journal of Business Research 33 (1), 57-66.

Heilman, Carrie M., Kent Nakamoto, and Ambar G. Rao (2002). "Pleasant Surprises: Consumer Response to Unexpected in-Store Coupons." Journal of Marketing Research 39 (2), 242-52.

Horowitz, John, J. List, and K. E. McConnell (2007). "A Test of Diminishing Marginal Value." Economica 74 (296), 650-63.

IBISWorld (2016). "Promotional Products in the Us: Market Research Report." https://www.ibisworld.com/industry/default.aspx?indid=1440. Accessed August 2016.

Jones, Joseph M. (2008). "An Exploratory Study on Attitude Persistence Using Sales Promotion." Journal of Managerial Issues 20 (3), 401-16.

--- (2015). "Post-Promotion Effects of Free Gift Premiums: Examining the Moderating Role of Need for Cognition." Journal of Marketing Development and Competitiveness 9 (1), 74.

Kahneman, Daniel and Amos Tversky (1979). "Prospect Theory: An Analysis of Decision under Risk." Econometrica 47 (2), 263-91.

Kivetz, Ran (2005). "Promotion Reactance: The Role of Effort-Reward Congruity." Journal of Consumer Research 31 (4), 725-36.

Kumar, Nanda, Surendra Rajiv, and Abel Jeuland (2001). "Effectiveness of Trade Promotions: Analyzing the Determinants of Retail Pass Through." Marketing Science 20 (4), 382-404.

Low, George S. and Donald Jr. Lichtenstein (1993). "Technical Research Note: The Effect of Double Deals on Consumer Attitudes." Journal of Retailing 69 (4), 453-66.

Massara, Francesco, RobertD Melara, and SandraS Liu (2014). "Impulse Versus Opportunistic Purchasing During a Grocery Shopping Experience." Marketing Letters 25 (4), 361-72.

Mazodier, Marc and Pascale Quester (2014). "The Role of Sponsorship Fit for Changing Brand Affect: A Latent Growth Modeling Approach." International Journal of Research in Marketing 31 (1), 16-29.

Minnema, Alec, Tammo H. A. Bijmolt, and Mariëlle C. Non (2016). "The Impacts of Instant Reward Programs and Bonus Premiums on Product Sales." International Journal of Research in Marketing (Forthcoming).

Montaner, Teresa, Leslie de Chernatony, and Isabel Buil (2011). "Consumer Response to Gift Promotions." Journal of Product \& Brand Management 20 (2), 101-10.

Narasimhan, Chakravarthi, Scott A. Neslin, and Subrata K. Sen (1996). "Promotional Elasticities and Category Characteristics." Journal of Marketing 60 (2), 17-31.

Neslin, Scott A. (2006). "Sales Promotion." Pp 310-38 in Handbook of Marketing, Robin Wensley and Barton A. Weitz (eds). London, Thousand Oaks, New Delhi: Sage.

Nielsen (2016). "Trade Promotion Doesn't Have to Be a Guessing Game." http://viz.nielsen.com/tradepromotionperformance/. Accessed November 8, 2017.

Nunes, Joseph C. and C. Whan Park (2003). "Incommensurate Resources: Not Just More of the Same." Journal of Marketing Research 40 (1), 26-38.

Palazón-Vidal, Mariola and Elena Delgado-Ballester (2005). "Sales Promotions Effects on Consumer-Based Brand Equity." International Journal of Market Research 47 (2), 179-204.

Palazon, Mariola and Elena Delgado-Ballester (2009). "Effectiveness of Price Discounts and Premium Promotions." Psychology \& Marketing 26 (12), 1108-29. 
Palazon, Mariola and Elena Delgado-Ballester (2013). "Hedonic or Utilitarian Premiums: Does It Matter?" European Journal of Marketing 47 (8), 1256-75.

Palazon, Mariola and Elena Delgado (2009). "The Moderating Role of Price Consciousness on the Effectiveness of Price Discounts and Premium Promotions." Journal of Product \& Brand Management 18 (4), 306-12.

Raghubir, Priya (2005). "Framing a Price Bundle: The Case of "Buy/Get" Offers." Journal of Product \& Brand Management 14 (2), 123-28.

--- (2004). "Free Gift with Purchase: Promoting or Discounting the Brand?" Journal of Consumer Psychology 14 (1/2), 181-86.

Raghubir, Priya and Kirti Sawhney Celly (2011). "Promoting Promotions: Does Showcasing Free Gifts Backfire?" Journal of Business Research 64 (1), 55-58.

Raghunathan, Rajagopal and Kim Corfman (2006). "Is Happiness Shared Doubled and Sadness Shared Halved? Social Influence on Enjoyment of Hedonic Experiences." Journal of Marketing Research 43 (3), 386-94.

Rudek, Stefanie (2008). Organisation Der Verkaufsförderung Bei Konsumgüterherstellern. Wiesbaden: Gabler.

Shimp, Terence A., Robert F. Dyer, and Salvatore F. Divita (1976). "An Experimental Test of the Harmful Effects of Premium-Oriented Commercials on Children." Journal of Consumer Research 3 (1), 1-47.

Silva-Risso, Jorge M., Randolph E. Bucklin, and Donald G. Morrison (1999). "A Decision Support System for Planning Manufacturers' Sales Promotion Calendars." Marketing Science 18 (3), 274-300.

Simonin, Bernard L and Julie A Ruth (1998). "Is a Company Known by the Company It Keeps? Assessing the Spillover Effects of Brand Alliances on Consumer Brand Attitudes." Journal of marketing research 35 (1), 30-42.

Simonson, Itamar, Ziv Carmon, and Suzanne O'Curry (1994). "Experimental Evidence on the Negative Effect of Product Features and Sales Promotions on Brand Choice." Marketing Science 13 (1), 23-40.

Sivakumar, K. and S.P. Raj (1997). "Quality Tier Competition: How Price Change Influences Brand Choice and Category Choice." Journal of Marketing 61 (3), 71-84.

Sloot, Laurens M., Peter C. Verhoef, and Philip Hans Franses (2005). "The Impact of Brand Equity and the Hedonic Level of Products on Consumer Stock-out Reactions." Journal of Retailing 81 (1), 15-34.

Srinivasan, Shuba, Koen Pauwels, Dominique M. Hanssens, and Marnik G. Dekimpe (2004). "Do Promotions Benefit Manufacturers, Retailers, or Both?" Management Science 50 (5), 617-29.

Train, Kenneth E. (2009). Discrete Choice Methods with Simulation. Cambridge, UK: Cambridge University Press.

Van Heerde, Harald J., Sachin Gupta, and Dick R. Wittink (2003). "Is 75\% of the Sales Promotion Bump Due to Brand Switching? No, Only 33\% Is." Journal of Marketing Research 40 (4), 481-91.

Venkatesh, R. and Wagner Kamakura (2003). "Optimal Bundling and Pricing under a Monopoly: Contrasting Complements and Substitutes from Independently Valued Products." Journal of Business 76 (2), 211-31.

Walters, Rockney G. (1989). "An Empirical Investigation into Retailer Response to Manufacturer Trade Promotions." Journal of Retailing 65 (2), 253. 


\section{Appendix: Selection of Categories, Assortments, and Promoted Brands}

We used GfK data to select categories with a sufficiently high penetration, high purchase frequencies, and tractable assortments. To ensure assortment tractability, we chose categories in which there is a common package size and a limited set of brands/flavors generates at least $75 \%$ of the category's sales. In our shopping simulation, this enabled us to compose limited assortments with a single package size that still looked realistic and complete. We retained four categories: orange juice, cereals, margarine, and milk. Notice that this selection offers sufficient variation to ensure generalizability of our results. For example, prior literature has classified orange juice and cereals as hedonic in nature and margarine and milk as utilitarian (Breugelmans, Campo and Gijsbrechts 2006; Campo, Gijsbrechts and Nisol 2000; Sloot, Verhoef and Franses 2005; Raghunathan and Corfman 2006).

To allow for a comparison of promotion effects between national brand and private label products, we included the house brand of a major supermarket chain in all four categories. In each category, we chose a major national brand with a comparable product range as the private label. In the experiment, we alternately promoted SKUs of the national brand and the private label to be able to examine the role of brand type. The set of promoted SKUs of the national brand matched that of the private label in size and product characteristics. For example, in the milk category, we promoted the skimmed, semi-skimmed, and whole versions of either the national brand or the private label. At the end of our main study, respondents evaluated the perceived quality of both brands on a seven-point semantic differential scale (cf. Aaker and Keller 1990) (see table below). The results indicate that, in all categories, the private label was perceived to be of significantly lower quality than the national brand $(p<.01)$.

Finally, in each category, we determined the SKUs' off-deal prices based on regular prices recorded in four supermarkets. 
Manipulation Check for Perceived Brand Quality (see Aaker and Keller 1990)

\begin{tabular}{lccrrr}
\hline & & Juice & Cereals & Margarine & Milk \\
How would you rate the quality of [brand name]? & & & & \\
Very low/Very high (1-7) & Private Label & 3.27 & 3.55 & 2.19 & 2.56 \\
& National Brand & 4.44 & 4.31 & 4.80 & 5.36
\end{tabular}




\section{Table 1}

\section{Relevant Literature and Contribution}

Moderators

\begin{tabular}{|c|c|c|c|c|c|}
\hline Study & Data & Dependent variable & $\begin{array}{c}\text { Comparison } \\
\text { with price cut }\end{array}$ & $\begin{array}{l}\text { Functional } \\
\text { relatedness }\end{array}$ & $\begin{array}{l}\text { Brand equity/ } \\
\text { product } \\
\text { quality/attitude }\end{array}$ \\
\hline $\begin{array}{l}\text { Chandran and } \\
\text { Morwitz (2006) }\end{array}$ & $\begin{array}{l}\text { Scenario-based } \\
\text { experiment }\end{array}$ & $\begin{array}{l}\text { Product quality, purchase } \\
\text { intention }\end{array}$ & $\mathrm{X}$ & & \\
\hline Chou and Lien (2012) & $\begin{array}{l}\text { Scenario-based } \\
\text { experiment }\end{array}$ & Ad attitude, product attitude & $\mathrm{X}$ & & \\
\hline $\begin{array}{l}\text { Darke and Chung } \\
\text { (2005) }\end{array}$ & $\begin{array}{l}\text { Scenario-based } \\
\text { experiment }\end{array}$ & $\begin{array}{l}\text { Deal attractiveness, product } \\
\text { quality }\end{array}$ & $\mathrm{X}$ & & \\
\hline \multirow[t]{2}{*}{$\begin{array}{l}\text { Nunes and Park } \\
(2003)\end{array}$} & $\begin{array}{l}\text { Scenario-based } \\
\text { experiment }\end{array}$ & Store switching intention & $\mathrm{X}$ & & \\
\hline & $\begin{array}{l}\text { Field } \\
\text { experiment }\end{array}$ & Brand sales & $\mathrm{X}$ & & \\
\hline $\begin{array}{l}\text { Palazon and Delgado- } \\
\text { Ballester (2009) }\end{array}$ & $\begin{array}{l}\text { Scenario-based } \\
\text { experiment }\end{array}$ & $\begin{array}{l}\text { Deal attractiveness, search } \\
\text { intention, purchase intention }\end{array}$ & $\mathrm{X}$ & & \\
\hline $\begin{array}{l}\text { Palazon and Delgado } \\
\text { (2009) }\end{array}$ & $\begin{array}{l}\text { Scenario-based } \\
\text { experiment }\end{array}$ & $\begin{array}{l}\text { Deal attractiveness, purchase } \\
\text { intention }\end{array}$ & $\mathrm{X}$ & & \\
\hline $\begin{array}{l}\text { Buil, de Chernatony } \\
\text { and Montaner (2013) }\end{array}$ & $\begin{array}{l}\text { Scenario-based } \\
\text { experiment }\end{array}$ & Deal attractiveness & & $\mathrm{X}$ & $\mathrm{X}$ \\
\hline $\begin{array}{l}\text { d'Astous and Jacob } \\
(2002)\end{array}$ & Survey & Deal attractiveness & & & $\mathrm{X}$ \\
\hline $\begin{array}{l}\text { d'Astous and } \\
\text { Landreville (2003) }\end{array}$ & $\begin{array}{l}\text { Scenario-based } \\
\text { experiment }\end{array}$ & Deal attractiveness & & $\mathrm{X}$ & \\
\hline Gaeth et al. (1990) & $\begin{array}{l}\text { Scenario-based } \\
\text { experiment }\end{array}$ & Product evaluation & & $\mathrm{X}$ & $\mathrm{X}$ \\
\hline Harlam et al. (1995) & $\begin{array}{l}\text { Scenario-based } \\
\text { experiment }\end{array}$ & Purchase intention & & $\mathrm{X}$ & \\
\hline Jones (2008) & $\begin{array}{l}\text { Scenario-based } \\
\text { experiment }\end{array}$ & Product attitude & & $\mathrm{X}$ & \\
\hline Jones (2015) & $\begin{array}{l}\text { Scenario-based } \\
\text { experiment }\end{array}$ & $\begin{array}{l}\text { Product attitude, purchase } \\
\text { intention }\end{array}$ & & $\mathrm{X}$ & \\
\hline $\begin{array}{l}\text { Montaner, de } \\
\text { Chernatony and Buil } \\
\text { (2011) }\end{array}$ & $\begin{array}{l}\text { Scenario-based } \\
\text { experiment }\end{array}$ & $\begin{array}{l}\text { Deal attractiveness, purchase } \\
\text { intention }\end{array}$ & & & $\mathrm{X}$ \\
\hline Our Study & $\begin{array}{l}\text { Purchase } \\
\text { simulation }\end{array}$ & $\begin{array}{l}\text { Category purchase incidence, } \\
\text { brand choice, purchase } \\
\text { quantity }\end{array}$ & $\mathrm{X}$ & $\mathrm{X}$ & $\mathrm{X}$ \\
\hline
\end{tabular}


Table 2

Assortment and Promotion Characteristics in Shopping Experiment

\begin{tabular}{|c|c|c|c|c|c|c|c|c|c|c|c|c|c|c|}
\hline \multirow[b]{2}{*}{ Category } & \multicolumn{4}{|c|}{ Assortment Characteristics } & \multirow[b]{2}{*}{$\begin{array}{c}\text { No. of } \\
\text { SKUs on } \\
\text { Promotion }\end{array}$} & \multicolumn{3}{|c|}{ Functionally Related Premium } & \multicolumn{3}{|c|}{ Unrelated Premium } & \multicolumn{3}{|c|}{ Price Cut Levels } \\
\hline & $\begin{array}{c}\text { Market } \\
\text { Share of } \\
\text { Selected } \\
\text { Brands } \\
\text { (GfK) }\end{array}$ & $\begin{array}{c}\text { No. } \\
\text { of } \\
\text { SKUs }\end{array}$ & $\begin{array}{l}\text { Package } \\
\text { Size }\end{array}$ & $\begin{array}{l}\text { Av. } \\
\text { Regular } \\
\text { Price } \\
\text { across } \\
\text { SKUs } \\
\end{array}$ & & Item & $\begin{array}{c}\text { Av. } \\
\text { Perceived } \\
\text { Value }\end{array}$ & $\begin{array}{l}\text { Functional } \\
\text { Relatedness } \\
\text { Score }(1-7)\end{array}$ & Item & $\begin{array}{c}\text { Av. } \\
\text { Perceived } \\
\text { Value }\end{array}$ & $\begin{array}{l}\text { Functional } \\
\text { Relatedness } \\
\text { Score (1-7) }\end{array}$ & Low & Medium & High \\
\hline Orange Juice & $83 \%$ & 10 & 1 liter & $€ 1.50$ & 2 & Glass & $€ .40$ & 6.33 & Key chain & $€ .35$ & 1.76 & $€ .20$ & $€ .35$ & $€ .50$ \\
\hline Cereals & $93 \%$ & 42 & 500 gram & $€ 3.25$ & 3 & Bowl & $€ .62$ & 6.44 & Key tag & $€ .62$ & 2.16 & $€ .30$ & $€ .60$ & $€ .90$ \\
\hline Margarine & $98 \%$ & 18 & 250 gram & $€ 2.09$ & 2 & Spreading knife & $€ .59$ & 6.14 & Pen & $€ .55$ & 1.86 & $€ .15$ & $€ .35$ & $€ .55$ \\
\hline Milk & $75 \%$ & 18 & 1 liter & $€ 1.11$ & 3 & $\begin{array}{l}\text { Carton/ bottle } \\
\text { holder }\end{array}$ & $€ .29$ & 5.15 & $\begin{array}{l}\text { Set of red } \\
\text { magnets }\end{array}$ & $€ .28$ & 2.14 & $€ .15$ & $€ .25$ & $€ .35$ \\
\hline
\end{tabular}


Table 3

Sample Characteristics

\begin{tabular}{lc}
\hline $\begin{array}{l}\text { Socio-Demographic } \\
\text { Variable }\end{array}$ & Percentage \\
\hline Gender & \\
Female & $80 \%$ \\
Male & $20 \%$ \\
Age & \\
35 or below & $30 \%$ \\
36 till 55 & $45 \%$ \\
56 or above & $25 \%$ \\
Children living at home & \\
None & $52 \%$ \\
1-2 & $39 \%$ \\
3 or more & $9 \%$ \\
Occupation & \\
Student & $4 \%$ \\
Housewife/-husband & $9 \%$ \\
Part-time employed & $19 \%$ \\
Full-time employed & $46 \%$ \\
Unemployed & $4 \%$ \\
Retired & $15 \%$ \\
Other & $5 \%$ \\
\hline Sample size (n) & 2,027 \\
\hline
\end{tabular}




\section{Table 4}

Descriptives for Consumer Response With and Without Promotions

\begin{tabular}{|c|c|c|c|c|c|c|c|c|c|c|}
\hline \multirow[b]{2}{*}{ Category } & \multirow{2}{*}{$\begin{array}{l}\text { No. of } \\
\text { Respondents } \\
\text { (Purchase } \\
\text { Occasions) }\end{array}$} & \multicolumn{3}{|c|}{ Incidence Rates (\%) } & \multicolumn{3}{|c|}{ Average Choice Shares (\%) } & \multicolumn{3}{|c|}{ Average Purchase Quantities (units) } \\
\hline & & $\begin{array}{c}\text { No } \\
\text { Promotion }\end{array}$ & Price Cut & Premium & $\begin{array}{c}\text { No } \\
\text { Promotion }\end{array}$ & Price Cut & Premium & $\begin{array}{c}\text { No } \\
\text { Promotion }\end{array}$ & Price Cut & Premium \\
\hline Orange Juice & $975(5,850)$ & 51 & 55 & 54 & 14 & 29 & 21 & 3.0 & 3.3 & 2.9 \\
\hline Cereals & $671(4,026)$ & 44 & 47 & 48 & 4 & 8 & 7 & 1.1 & 1.3 & 1.3 \\
\hline Margarine & $898(5,388)$ & 39 & 43 & 45 & 8 & 18 & 14 & 1.4 & 1.8 & 1.4 \\
\hline Milk & $1,175(7,050)$ & 48 & 58 & 57 & 12 & 21 & 17 & 4.5 & 5.4 & 4.5 \\
\hline
\end{tabular}

\section{Table 5}

Hypotheses and Tests

\begin{tabular}{|c|c|c|c|c|c|c|}
\hline \multirow[b]{2}{*}{ Hypothesis } & & \multirow[b]{2}{*}{ Expected Effect } & \multicolumn{3}{|c|}{ Test Results ${ }^{\mathrm{a}}$} & \multirow[b]{2}{*}{ Milk } \\
\hline & & & Juice & Cereals & Margarine & \\
\hline \multirow{2}{*}{$\begin{array}{l}\mathrm{H}_{1} \text { : Premium has smaller effect than } \\
\text { equivalent price cut. }\end{array}$} & $\mathrm{H}_{1 \mathrm{a}}$ : Choice & $\beta_{2}<\beta_{5}$ & $1.56<2.89$ & $1.31<1.43$ & $1.85<3.29$ & $.07<.25$ \\
\hline & $\mathrm{H}_{1 \mathrm{~b}}$ : Quantity & $\gamma_{2}<\gamma_{5}$ & $.06<.27$ & $.47<.76$ & $-.05<.79$ & $.07<.25$ \\
\hline \multirow{2}{*}{$\begin{array}{l}\mathrm{H}_{2} \text { : Comparative premium } \\
\text { effectiveness is higher for related } \\
\text { than for unrelated premium. }\end{array}$} & $\mathrm{H}_{2 \mathrm{a}}$ : Choice & $\beta_{3}>0$ & $.56>0$ & $.27>0$ & $.48>0$ & $-.01<0$ \\
\hline & $\mathrm{H}_{2 \mathrm{~b}}$ : Quantity & $\gamma_{3}>0$ & $-.08<0$ & $.08>0$ & $-.23<0$ & $-.06<0$ \\
\hline \multirow{2}{*}{$\begin{array}{l}\mathrm{H}_{3} \text { : Comparative premium } \\
\text { effectiveness is higher for private } \\
\text { labels than for national brands. }\end{array}$} & $\mathrm{H}_{3 \mathrm{a}}$ : Choice & $\beta_{4}<\beta_{6}$ & $-.08<.64$ & $-.53>-.58$ & $.30<2.06$ & $.65<2.91$ \\
\hline & $\mathrm{H}_{3 \mathrm{~b}}$ : Quantity & $\gamma_{4}<\gamma_{6}$ & $-.03<.12$ & $-.46<-.40$ & $-.12>-.43$ & $-.08>-.18$ \\
\hline
\end{tabular}

${ }^{a}$ Results in bold are significant at the $p<.05$ level (two-sided).

${ }^{\mathrm{b}}$ We compute the t-statistic for $\mathrm{H}_{1}$ as $\left(\beta_{2}-\beta_{5}\right) / \sqrt{\operatorname{var}\left(\beta_{2}\right)+\operatorname{var}\left(\beta_{5}\right)-2 \times \operatorname{cov}\left(\beta_{2}, \beta_{5}\right)}$ for the choice model, and as

$\left(\gamma_{2}-\gamma_{5}\right) / \sqrt{\operatorname{var}\left(\gamma_{2}\right)+\operatorname{var}\left(\gamma_{5}\right)-2 \times \operatorname{cov}\left(\gamma_{2}, \gamma_{5}\right)}$ for the quantity model, where the denominators represent the standard errors of the differences in the numerators. We use an analogous approach to test $\mathrm{H}_{3}$. 


\section{Table 6}

Model Estimates ${ }^{\mathrm{a}}$

\begin{tabular}{|c|c|c|c|c|c|c|c|c|}
\hline & \multicolumn{2}{|c|}{ Orange Juice $^{b}$} & \multicolumn{2}{|c|}{ Cereals } & \multicolumn{2}{|c|}{ Margarine } & \multicolumn{2}{|c|}{ Milk } \\
\hline & Mean & St. Dev. & Mean & St. Dev. & Mean & St. Dev. & Mean & St. Dev. \\
\hline \multicolumn{9}{|l|}{ Purchase Incidence } \\
\hline Inventory & $-9.84(.52)^{\mathfrak{c}}$ & $\mathbf{6 . 1 5}(.36)$ & $-\mathbf{3 1 . 2 5}(1.74)$ & $20.72(1.16)$ & $-\mathbf{2 8 . 5 5}(1.64)$ & $16.15(.92)$ & $-8.34(.40)$ & $6.34(.32)$ \\
\hline Usual inter-purchase time & $-\mathbf{1 . 0 0}(.06)$ & $.30(.04)$ & $-1.21(.07)$ & $.36(.04)$ & $-\mathbf{1 . 0 0}(.06)$ & $.32(.05)$ & $\mathbf{- 1 . 3 7}(.07)$ & $.37(.05)$ \\
\hline Scale parameter & $.29(.05)$ & $.19(.03)$ & $.02(.01)$ & $.01(.01)$ & $.06(.03)$ & $.04(.02)$ & $.13(.04)$ & $.09(.03)$ \\
\hline \multicolumn{9}{|l|}{ Brand Choice } \\
\hline Loyalty & $3.88(.15)$ & $1.35(.20)$ & $7.15(.22)$ & $4.17(.23)$ & $\mathbf{5 . 6 8}(.23)$ & $.75(.39)$ & $4.46(.17)$ & $1.95(.18)$ \\
\hline Purchase feedback dummy & $2.11(.10)$ & $\mathbf{1 . 8 0}(.11)$ & $.75(.10)$ & $2.04(.11)$ & $2.58(.15)$ & $2.05(.15)$ & $2.89(.10)$ & $2.13(.12)$ \\
\hline Premium dummy (PREM) & $1.56(.11)$ & $.45(.17)$ & $1.31(.14)$ & $.48(.19)$ & $1.85(.17)$ & $.19(.28)$ & $1.61(.11)$ & $.09(.21)$ \\
\hline Related premium $(\mathrm{PREM} \times \mathrm{REL})$ & $.56(.19)$ & $.47(.34)$ & $.27(.25)$ & $.01(.37)$ & $.48(.27)$ & $.62(.39)$ & $-.01(.19)$ & $.59(.30)$ \\
\hline Premium for nat. brand $(\mathrm{PREM} \times \mathrm{NB})$ & $-.08(.25)$ & $.38(.33)$ & $-.53(.27)$ & $.25(.37)$ & $.30(.37)$ & $.80(.48)$ & $.65(.26)$ & $.13(.33)$ \\
\hline Discount size (DISC) & $2.89(.11)$ & $.64(.15)$ & $1.43(.10)$ & $.02(.16)$ & $3.29(.21)$ & $.10(.60)$ & $3.27(.13)$ & $1.09(.19)$ \\
\hline Discount for nat. brand (DISC × NB) & $.64(.22)$ & $.63(.27)$ & $-.58(.19)$ & $.11(.24)$ & $2.06(.44)$ & $.35(.51)$ & $2.91(.29)$ & $1.06(.34)$ \\
\hline \multicolumn{9}{|l|}{ Purchase Quantity } \\
\hline Inventory & $.11(.01)$ & $.07(.01)$ & $-.27(.25)$ & $.23(.21)$ & $-.36(.16)$ & $1.11(.28)$ & $-.22(.02)$ & $.39(.02)$ \\
\hline Loyalty & $.11(.06)$ & $.66(.04)$ & $.86(.21)$ & $.13(.13)$ & $.27(.13)$ & $.39(.15)$ & $.10(.04)$ & $.44(.03)$ \\
\hline Usual purchase amount & $22.33(.56)$ & $9.44(.38)$ & $31.60(2.46)$ & $12.75(1.84)$ & $45.27(3.00)$ & $8.62(1.67)$ & $12.63(.23)$ & $\mathbf{5 . 0 9}(.17)$ \\
\hline Premium dummy (PREM) & $.06(.04)$ & $.07(.05)$ & $.47(.21)$ & $.20(.20)$ & $-.05(.13)$ & $.01(.13)$ & $.07(.03)$ & $.03(.03)$ \\
\hline Related premium $(\mathrm{PREM} \times \mathrm{REL})$ & $-.08(.07)$ & $.17(.09)$ & $.08(.35)$ & $.10(.36)$ & $-.23(.22)$ & $.40(.22)$ & $-.06(.04)$ & $.12(.06)$ \\
\hline Premium for nat. brand $(\mathrm{PREM} \times \mathrm{NB})$ & $-.03(.09)$ & $.24(.09)$ & $-.46(.44)$ & $.01(.38)$ & $-.12(.26)$ & $.27(.33)$ & $-.08(.05)$ & $.14(.06)$ \\
\hline Discount size (DISC) & $.27(.03)$ & $.01(.04)$ & $.76(.16)$ & $.11(.14)$ & $.79(.13)$ & $.23(.13)$ & $.25(.02)$ & $.07(.04)$ \\
\hline Discount for nat. brand (DISC $\times$ NB) & $.12(.06)$ & $.16(.06)$ & $-.40(.32)$ & $.05(.31)$ & $-.43(.25)$ & $.11(.39)$ & $-.18(.05)$ & $.11(.06)$ \\
\hline Log Likelihood & \multicolumn{2}{|c|}{$-2,647.41$} & \multicolumn{2}{|c|}{$-8,717.19$} & \multicolumn{2}{|c|}{$-5,846.46$} & \multicolumn{2}{|c|}{$8,789.36$} \\
\hline
\end{tabular}

${ }^{a}$ Estimates for the attribute-specific intercepts and the cross-sectional and contemporaneous correlations are available on request.

$\mathrm{b}$ The numbers in the two columns for each category represent the mean and standard deviation of the normal parameter distributions, capturing latent heterogeneity.

${ }^{c}$ Numbers in bold are significant at least at the $p<.05$ level (two-sided). Standard errors are reported in brackets. 


\section{Table 7}

Sales Impact of Premiums and Equivalent Price Cuts

a. Percentage Increase in Unit Sales of Promoted SKUs

\begin{tabular}{llcc}
\hline \multirow{2}{*}{ Orange Juice } & Premium & Equivalent Price Cut \\
& Private Label & $73.21 \%$ & $151.94 \%$ \\
\multirow{2}{*}{ Cereals } & Private Label & $158.68 \%$ & $185.53 \%$ \\
& National Brand & $48.81 \%$ & $60.56 \%$ \\
\multirow{2}{*}{ Margarine } & Private Label & $69.80 \%$ & $219.01 \%$ \\
& National Brand & $43.91 \%$ & $198.42 \%$ \\
\multirow{2}{*}{ Milk } & Private Label & $37.42 \%$ & $86.87 \%$ \\
& National Brand & $46.86 \%$ & $172.00 \%$ \\
\hline
\end{tabular}

b. Percentage Increase in Category Unit Sales

\begin{tabular}{llcc}
\hline & & Premium & Equivalent Price Cut \\
\hline \multirow{2}{*}{ Orange Juice } & Private Label & $1.38 \%$ & $8.71 \%$ \\
& National Brand & $1.66 \%$ & $20.13 \%$ \\
\multirow{2}{*}{ Cereals } & Private Label & $1.14 \%$ & $1.85 \%$ \\
& National Brand & $1.27 \%$ & $2.84 \%$ \\
\multirow{3}{*}{ Margarine } & Private Label & $1.26 \%$ & $18.55 \%$ \\
& National Brand & $.54 \%$ & $18.09 \%$ \\
\multirow{2}{*}{ Milk } & Private Label & $5.58 \%$ & $21.69 \%$ \\
& National Brand & $2.88 \%$ & $16.73 \%$ \\
\hline
\end{tabular}

Table 8

Indifference Cost-Value Ratios

\begin{tabular}{|c|c|c|c|}
\hline & & $\begin{array}{c}\text { Cost-value ratio leading to } \\
\text { indifference in terms of sales of } \\
\text { promoted SKUs }\end{array}$ & $\begin{array}{c}\text { Cost-value ratio leading to } \\
\text { indifference in terms of category } \\
\text { sales }\end{array}$ \\
\hline \multirow{2}{*}{ Orange Juice } & Private Label & $54.45 \%{ }^{\mathrm{a}}$ & $34.32 \%$ \\
\hline & National Brand & $38.77 \%$ & $18.79 \%$ \\
\hline \multirow{2}{*}{ Cereals } & Private Label & $90.49 \%$ & $79.84 \%$ \\
\hline & National Brand & $84.01 \%$ & $56.46 \%$ \\
\hline \multirow{2}{*}{ Margarine } & Private Label & $47.62 \%$ & $17.73 \%$ \\
\hline & National Brand & $34.48 \%$ & $6.09 \%$ \\
\hline \multirow{2}{*}{ Milk } & Private Label & $46.97 \%$ & $34.19 \%$ \\
\hline & National Brand & $35.56 \%$ & $26.17 \%$ \\
\hline
\end{tabular}

${ }^{a}$ For example, a retailer interested in the performance of his private label in the orange juice category should prefer the premium to a price cut as long as the premium's cost is less than $54.45 \%$ of the premium's perceived value. 
Table 9

Occurrence of Premium Promotions and Price Cuts Based on Store Flyer Information

\begin{tabular}{lccc}
\hline & Premium Promotions & Price Cuts & Total \\
\hline \multirow{2}{*}{ Juice } & 83 & 545 & 628 \\
& $(13.22 \%)$ & $(86.78 \%)$ & $(100 \%)$ \\
Cereals & 95 & 398 & 493 \\
& $(19.27 \%)$ & $(80.73 \%)$ & $(100 \%)$ \\
Margarine & 179 & 436 & 615 \\
& $(29.11 \%)$ & $(70.89 \%)$ & $(100 \%)$ \\
Milk & 28 & 271 & 299 \\
& $(9.36 \%)$ & $(90.64 \%)$ & $(100 \%)$ \\
Total & 385 & 1,650 & 2,035 \\
& $(18.92 \%)$ & $(81.08 \%)$ & $(100 \%)$ \\
\hline
\end{tabular}




\section{Figure 1}

Conceptual Framework

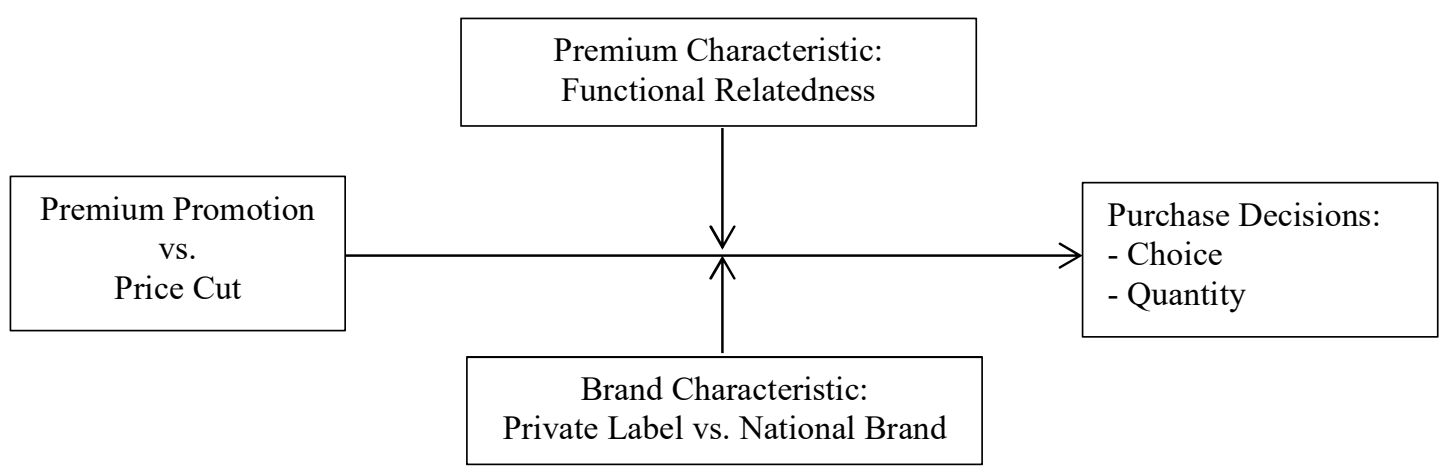




\section{Figure 2}

Simulated Shelf in the Margarine Category ${ }^{\mathrm{a}}$

a. Premium Promotion

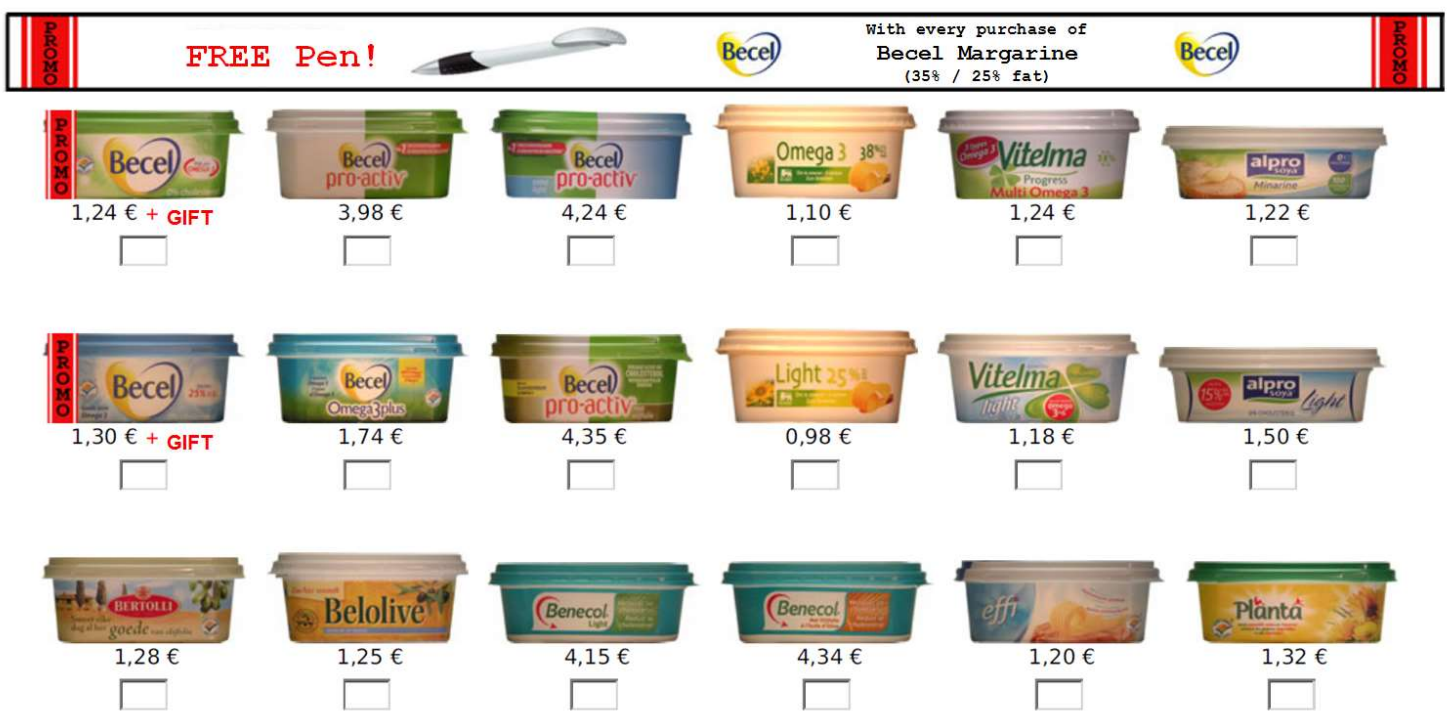

b. Price Cut

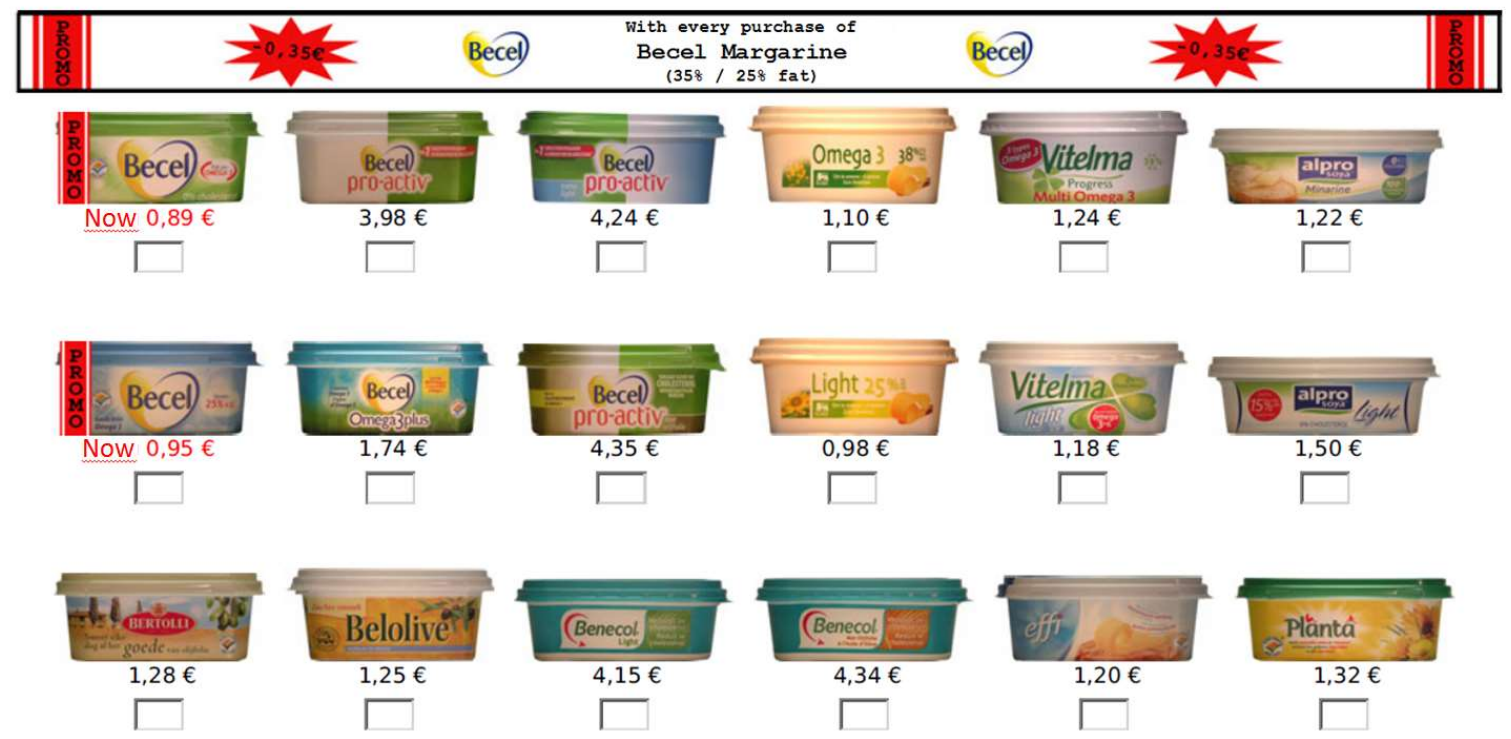

${ }^{a}$ The actual shopping experiment was in local language. 


\section{Web Appendix}

\section{A. Hypotheses Tests Based on Percentage Changes}

To calculate percentage changes in choice probabilities and purchase quantities, we first derived consumer-specific coefficients as the means of consumers' posterior parameter distributions (Train 2009). Based on these consumer-specific coefficients and using consumer-specific average values for the control variables, we simulated purchase behavior for each consumer in our dataset, in response to the premium promotions and the equivalent price cuts from our shopping experiment. ${ }^{9}$ We then computed the percentage changes in the average choice probability and purchase quantity for the promoted items and retested our hypotheses with regard to the differences in these percentage effects across promotions. To obtain standard errors for these differences, we made use of the Delta Method (Foubert and Gijsbrechts 2016). Table WA1 reports the results of this analysis. Notice that for every test in Table 5, there are multiple tests in Table WA1. For example, to test $\mathrm{H}_{1}$ in terms of percentage changes, we consider the effects of both the related and unrelated premium, for a private label as well as a national brand, and compare these effects each time with the corresponding price cut effect.

These additional test results largely confirm our coefficient-based insights (see Table 5). Nonetheless, two differences are worth mentioning. First, the percentage changes in purchase quantity in the orange juice category lend support to $\mathrm{H}_{3 \mathrm{~b}}$, while the coefficient-based results do not. Second, the percentage changes in purchase quantity in the milk category suggest that comparative premium effectiveness is higher for national brands than for private labels (counter to $\mathrm{H}_{3 b}$ ), while the corresponding difference between coefficient estimates - though in the same direction - is not significant. Due to the exponential form of the quantity model, non-significant differences in coefficients can easily get inflated and become significant.

\footnotetext{
${ }^{9}$ In the juice and milk categories, we left out a few consumers for which the counterfactual simulation generated extremely high purchase quantities, even in the absence of promotions. Clearly, for these consumers, the estimated Poisson model did not fit well.
} 


\section{Table WA1}

Hypotheses Tests on the Basis of Percentage Changes in Choice Probability and Purchase Quantity

\begin{tabular}{|c|c|c|c|c|c|c|c|c|c|c|c|}
\hline \multirow[b]{3}{*}{ Hypothesis } & & \multirow[b]{3}{*}{ Expected Effect ${ }^{\mathrm{b}}$} & \multicolumn{9}{|c|}{ Test Results $^{\mathrm{a}}$} \\
\hline & & & & \multicolumn{2}{|c|}{ Juice } & \multicolumn{2}{|c|}{ Cereals } & \multicolumn{2}{|c|}{ Margarine } & \multicolumn{2}{|c|}{ Milk } \\
\hline & & & & PL & NB & PL & NB & PL & NB & PL & NB \\
\hline \multirow{4}{*}{$\begin{array}{l}\mathrm{H}_{1} \text { : Premium has } \\
\text { smaller effect than } \\
\text { equivalent price cut. }\end{array}$} & \multirow{2}{*}{$\mathrm{H}_{1 \mathrm{a}}$ : Choice } & \multirow{2}{*}{$\% \Delta \mathrm{P}^{\mathrm{Prem}}<\% \Delta \mathrm{P}^{\mathrm{PC}}$} & Related & $84 \%<120 \%$ & $64 \%<123 \%$ & $137 \%>135 \%$ & $47 \%>44 \%$ & $101 \%<127 \%$ & $65 \%<156 \%$ & $32 \%<46 \%$ & $50 \%<141 \%$ \\
\hline & & & Unrelated & $57 \%<120 \%$ & $42 \%<123 \%$ & $106 \%<135 \%$ & $34 \%<44 \%$ & $72 \%<127 \%$ & $48 \%<156 \%$ & $32 \%<46 \%$ & $51 \%<141 \%$ \\
\hline & \multirow{2}{*}{$\mathrm{H}_{1 \mathrm{~b}}$ : Quantity } & \multirow{2}{*}{$\% \Delta Q^{\mathrm{Prem}}<\% \Delta \mathrm{Q}^{\mathrm{PC}}$} & Related & $2 \%<17 \%$ & $0 \%<29 \%$ & $8 \%<12 \%$ & $4 \%<7 \%$ & $-4 \%<76 \%$ & $-8 \%<34 \%$ & $6 \%<35 \%$ & $-1 \%<14 \%$ \\
\hline & & & Unrelated & $8 \%<17 \%$ & $6 \%<29 \%$ & $7 \%<12 \%$ & $3 \%<7 \%$ & $6 \%<76 \%$ & $1 \%<34 \%$ & $12 \%<35 \%$ & $4 \%<14 \%$ \\
\hline \multirow{2}{*}{$\begin{array}{l}\mathrm{H}_{2} \text { : Comparative } \\
\text { premium effectiveness } \\
\text { is higher for related } \\
\text { than for unrelated } \\
\text { premium. }\end{array}$} & ${ }_{\mathrm{s}} \mathrm{H}_{2 \mathrm{a}}:$ Choice & $\begin{array}{l}\% \Delta \mathrm{P}^{\text {RelPrem }}-\% \Delta \mathrm{P}^{\mathrm{PC}}> \\
\% \Delta \mathrm{P}^{\mathrm{UnrelPrem}}-\% \Delta \mathrm{P}^{\mathrm{PC}}\end{array}$ & & $-36 \%>-63 \%$ & $-59 \%>-81 \%$ & $2 \%>-29 \%$ & $3 \%>-10 \%$ & $-26 \%>-55 \%$ & $-91 \%>-108 \%$ & $-14 \%<-14 \%$ & $-91 \%<-90 \%$ \\
\hline & $\mathrm{H}_{2 \mathrm{~b}}$ : Quantity & $\begin{array}{l}\% \Delta \mathrm{Q}^{\mathrm{RelPrem}}-\% \Delta \mathrm{Q}^{\mathrm{PC}}> \\
\% \Delta \mathrm{Q}^{\text {UnrelPrem }}-\% \Delta \mathrm{Q}^{\mathrm{PC}}\end{array}$ & & $-15 \%<-9 \%$ & $-29 \%<-23 \%$ & $-4 \%>-5 \%$ & $-3 \%>-4 \%$ & $-80 \%<-70 \%$ & $-42 \%<-33 \%$ & $-29 \%<-23 \%$ & $-15 \%<-10 \%$ \\
\hline \multirow{4}{*}{$\begin{array}{l}\mathrm{H}_{3} \text { : Comparative } \\
\text { premium effectiveness } \\
\text { is higher for private } \\
\text { labels than for } \\
\text { national brands. }\end{array}$} & \multirow{2}{*}{${ }_{\mathrm{s}} \mathrm{H}_{3 \mathrm{a}}$ : Choice } & \multirow{2}{*}{$\begin{array}{l}\% \Delta \mathrm{P}^{\text {PLPrem }}-\% \Delta \mathrm{P}^{\mathrm{PLPC}}> \\
\% \Delta \mathrm{P}^{\mathrm{NBPrem}}-\% \Delta \mathrm{P}^{\mathrm{NBPC}}\end{array}$} & Related & \multicolumn{2}{|c|}{$-36 \%>-59 \%$} & \multicolumn{2}{|c|}{$2 \%<3 \%$} & \multicolumn{2}{|c|}{$-26 \%>-91 \%$} & \multicolumn{2}{|c|}{$-14 \%>-91 \%$} \\
\hline & & & Unrelated & \multicolumn{2}{|c|}{$-63 \%>-81 \%$} & \multicolumn{2}{|c|}{$-31 \%<-10 \%$} & \multicolumn{2}{|c|}{$-55 \%>-108 \%$} & \multicolumn{2}{|c|}{$-14 \%>-90 \%$} \\
\hline & \multirow{2}{*}{$\mathrm{H}_{3 \mathrm{~b}}$ : Quantity } & \multirow{2}{*}{$\begin{array}{c}\% \Delta Q^{\text {PLPrem }}-\% \Delta Q^{\text {PLPC }}> \\
\% \Delta Q^{\text {NBPrem }}-\% \Delta Q^{\text {NBPC }}\end{array}$} & Related & \multicolumn{2}{|c|}{$-15 \%>-29 \%$} & \multicolumn{2}{|c|}{$-4 \%<-3 \%$} & \multicolumn{2}{|c|}{$-80 \%<-42 \%$} & \multicolumn{2}{|c|}{$-29 \%<-15 \%$} \\
\hline & & & Unrelated & \multicolumn{2}{|c|}{$-9 \%>-23 \%$} & \multicolumn{2}{|c|}{$-5 \%<-4 \%$} & \multicolumn{2}{|c|}{$-70 \%<-33 \%$} & \multicolumn{2}{|c|}{$-23 \%<-10 \%$} \\
\hline
\end{tabular}

a Results in bold are significant at the $p<.05$ level (two-sided). The standard errors of the differences in percentage changes are obtained with the Delta Method. b $\% \Delta \mathrm{P}^{\text {Prem }}, \% \Delta \mathrm{P}^{\text {RelPrem }}, \% \Delta \mathrm{P}^{\text {UnrelPrem }} \% \Delta \mathrm{P}^{\mathrm{PLPrem}}, \% \Delta \mathrm{P}^{\mathrm{NBPrem}}, \% \Delta \mathrm{P}^{\mathrm{PC}}, \% \Delta \mathrm{P}^{\mathrm{PLPC}}, \% \Delta \mathrm{P}^{\mathrm{NBPC}}$ : percentage change in choice probability if there is a premium, a related premium, an unrelated premium, a premium for the private label, a premium for the national brand, a price cut, a price cut for the private label, a price cut for the national brand; $\% \Delta \mathrm{Q}^{\mathrm{Prem}}, \% \Delta \mathrm{Q}^{\text {RelPrem }}, \% \Delta \mathrm{Q}^{\text {UnrelPrem }}, \% \Delta \mathrm{Q}^{\mathrm{PLPrem}}, \% \Delta \mathrm{Q}^{\mathrm{NBPrem}}, \% \Delta \mathrm{Q}^{\mathrm{PC}}, \% \Delta \mathrm{Q}^{\mathrm{PLPC}}, \% \Delta \mathrm{Q}^{\mathrm{NBPC}}$ : percentage change in purchase quantity if there is a premium, a related premium, an unrelated premium, a premium for the private label, a premium for the national brand, a price cut, a price cut for the private label, a price cut for the national brand. 


\section{B. Additional Study on Perceived Premium Value}

We ran an additional study to illustrate how consumers' evaluations of a premium are influenced by the fact that the premium is offered as a promotional incentive. More precisely, we assessed the difference in willingness-to-pay (WTP) when the premium product is presented in isolation versus when it is offered for free, bundled with a promoted product. 173 students (after deletion of incomplete answers) from a large university participated for extra course credit. They were randomly assigned to either a premium-only (58 respondents) or a bundle condition (115 respondents). In the bundle condition, we further distinguished between combining the premium with a private label product (63 respondents) and combining it with a national brand (52 respondents), to control for differences in perceived quality between national brands and private labels.

Once assigned to one of the three conditions, respondents evaluated four premiums/bundles, presented in random order. Specifically, they indicated how much they would be willing to pay for the premium if it were for sale. The four premiums were the related premiums in the four categories used in our main study (bowl/cereals, glass/juice, knife/margarine, and carton holder/milk). Also the promoted (private label and national brand) products in the bundle conditions were those from our main study. Our ANOVA and post-hoc tests, of which the results are shown in Table WA2, indicate that, for all premiums/categories, the WTP of the premium in isolation was significantly higher $(p<$ $.01)$ than that of the premium in the bundle, with no significant difference $(p>.10)$ between the private label and national brand conditions. These results suggest that offering the premium for free together with a promoted product leads to devaluation of the premium (Darke and Chung 2005). 


\section{Table WA2}

\section{Tests of Difference in WTP for Premiums ${ }^{\mathrm{a}}$}

\footnotetext{
Cereals: $\mathrm{F}(170,2)=15.236 ; \mathrm{p}=.000$

$\mathrm{M}_{\text {PremOnly }}=2.04$ vs. $\mathrm{M}_{\text {bundlePL }}=.75 ; \mathrm{p}=.000^{\mathrm{b}}$

$\mathrm{M}_{\text {PremOnly }}=2.04$ vs. $\mathrm{M}_{\text {bundleNB }}=1.08 ; \mathrm{p}=.001$

$\mathrm{M}_{\text {bundlePL }}=.75$ vs. $\mathrm{M}_{\text {bundleNB }}=1.07 ; \mathrm{p}=.393$

Juice: $F(170,2)=18.162 ; p=.000$

$\mathrm{M}_{\text {PremOnly }}=1.55$ vs. $\mathrm{M}_{\text {bundlePL }}=.56 ; \mathrm{p}=.000$

$\mathrm{M}_{\text {PremOnly }}=1.55$ vs. $\mathrm{M}_{\text {bundleNB }}=.59 ; \mathrm{p}=.000$

$\mathrm{M}_{\text {bundlePL }}=.56$ vs. $\mathrm{M}_{\text {bundleNB }}=.58 ; \mathrm{p}=.990$

Margarine: $F(170,2)=20.740 ; p=.000$

$\mathrm{M}_{\text {PremOnly }}=1.50$ vs. $\mathrm{M}_{\text {bundlePL }}=.38 ; \mathrm{p}=.000$

$\mathrm{M}_{\text {PremOnly }}=1.50$ vs. $\mathrm{M}_{\text {bundleNB }}=.55 ; \mathrm{p}=.000$

$\mathrm{M}_{\text {bundlePL }}=.38$ vs. $\mathrm{M}_{\text {bundleNB }}=.55 ; \mathrm{p}=.650$

Milk: $\mathrm{F}(170,2)=52.504 ; \mathrm{p}=.000$

$\mathrm{M}_{\text {PremOnly }}=1.92$ vs. $\mathrm{M}_{\text {bundlePL }}=.38 ; \mathrm{p}=.000$

$\mathrm{M}_{\text {PremOnly }}=1.92$ vs. $\mathrm{M}_{\text {bundleNB }}=.46 ; \mathrm{p}=.000$

$\mathrm{M}_{\text {bundlePL }}=.38$ vs. $\mathrm{M}_{\text {bundleNB }}=.46 ; \mathrm{p}=.905$

${ }^{a} M_{\text {PremOnly: average WTP for premium in isolation; }}$

$\mathrm{M}_{\text {bundlePL }}$ : average WTP for premium in bundle with private label;

$M_{\text {bundleNB: }}$ average WTP for premium in bundle with national brand.

b We use Tukey's HSD as post-hoc test.
} 